\title{
JÍMKA 938 Z CHRUDIMI - HRADEBNÍ ULICE. POKUS O URČENÍ STATUTU JEJÍHO MAJITELE
}

\author{
JAN FROLÍK - ROMANA KOZÁKOVÁ - JAN MUSIL
}

Abstrakt: Detailní rozbor vybrané jímky z rozsáhlého záchranného archeologického výzkumu prokázal, že byla využivána po několik století a opakovaně zčásti vybirána a opětně zaplñována. Rozbor keramiky a skla vyčlenil až čtyři výrazné horizonty z obdobi 14. až 18. století. Obsah jimky svědči o bohatěji vybavené domácnosti s běžným uživáním širokého sortimentu skla a keramiky. Výrazně se ve výplni projevily události třicetileté války. Po metodické stránce jímka dokládá, že při pečlivé terénni práci může být významným svědectvím o každodenním životě na zkoumané parcele.

Klíčová slova: město - odpadní jímka - keramika - sklo - zacházení s odpadem.

\section{Refuse pit 938 in Chrudim, Hradebni Street. An attempt to determine the status of its owner}

Abstract: A detailed analysis of a selected refuse pit from extensive rescue research showed that it had been in use for several centuries, while regularly (partially) emptied and filled. The analysis of ceramic and glass from the refuse pit resulted in four distinct horizons spanning the 14th and the 18th century. The fill indicates a rich household with a wide assortment of glass and ceramic products. The events of the Thirty Years' War were reflected in the fill as well. In terms of methodology, the refuse pit manifests that given meticulous field research, these features can bring an important testimony concerning everyday life on the investigated site.

Key words: town - refuse pit-ceramic - glass - waste disposal.

\section{1 Úvod. Okolnosti výzkumu}

V roce 2006 proběhl v historickém jádru východočeského města Chrudimi dosud největší záchranný archeologický výzkum, a to v Hradební ulici na parcelách zaniklých domů čp. 14/I a 15/I a na zahradě původně náležející k čp. 10/I (obr. 1 a 2 - Frolík-Musil 2007; 2010). Záchranný archeologický výzkum získal významné svědectví o využití zkoumané plochy v pravěku (kultura slezskoplatěnická - Novák 2010) a pak kontinuálně od 9. století, kdy zde vzniklo hradiště, vyvíjející se ve významný článek přemyslovské správní soustavy v 11. až 13. století ve východních Čechách. Před rokem 1276 bylo na jeho místě lokováno vrcholně středověké město (Frolík-Sigl 1998). Na zkoumané ploše se to projevilo vyměřením tří městišt' přiléhajících na východní straně k ulici (dnes Hradební ulice). Domovní zástavba byla detailně zkoumána v severní části plochy, kde byl nalezen zaniklý dům dokládající, že zahrada novodobě náležející $\mathrm{k}$ domu čp. 10/I tvořila původně samostatné městiště. Počátky domu sahají do druhé poloviny 13. století, kdy byly evidovány dvě úrovně dřevěných srubových staveb. Na počátku 14. století nahradila srubové stavby opět dřevěná stavba, ale na kamenné podezdívce a nejméně dvouprostorová. Součástí stavby byl také zahloubený suterén se stěnami obloženými dřevem (Frolík-Musil 2014). Někdy během poloviny 14. století ho nahradila stavba, z níž se dochoval přibližně čtvercový sklep (rozměry $5 \times 5 \mathrm{~m}$ ) zděný z opuky na jíl. Jak vypadal dům stojící nad sklepem, nevíme, ale s největši pravděpodobností byl dřevěný. Ve století patnáctém byl v jeho těsném sousedství vyhlouben obdélný sklep o rozměrech zhruba $6 \times 4 \mathrm{~m}$, zděný na maltu a zaklenutý valenou klenbou. $V$ době jeho funkce bylo do podlahy sklepa vyhloubeno zděné schodiště, které ústilo do sklepa kř́žového půdorysu vyhloubeného hornickým způsobem. V této podobě se dům dožil třicetileté války, během níž byl pobořen. Obnoven již nebyl. Sklepy byly zavezeny stavebním odpadem a místo bylo využíváno jako zahrada. Majetkově bylo přičleněno k domu čp. 10/I.

Výraznou součástí nálezového obrazu jsou odpadní jímky a jámy (obr. 1). Jako jímky (celkem deset) označujeme v půdorysu pravidelné jámy (kruhové či pravoúhlé) obvykle s dřevěnou 


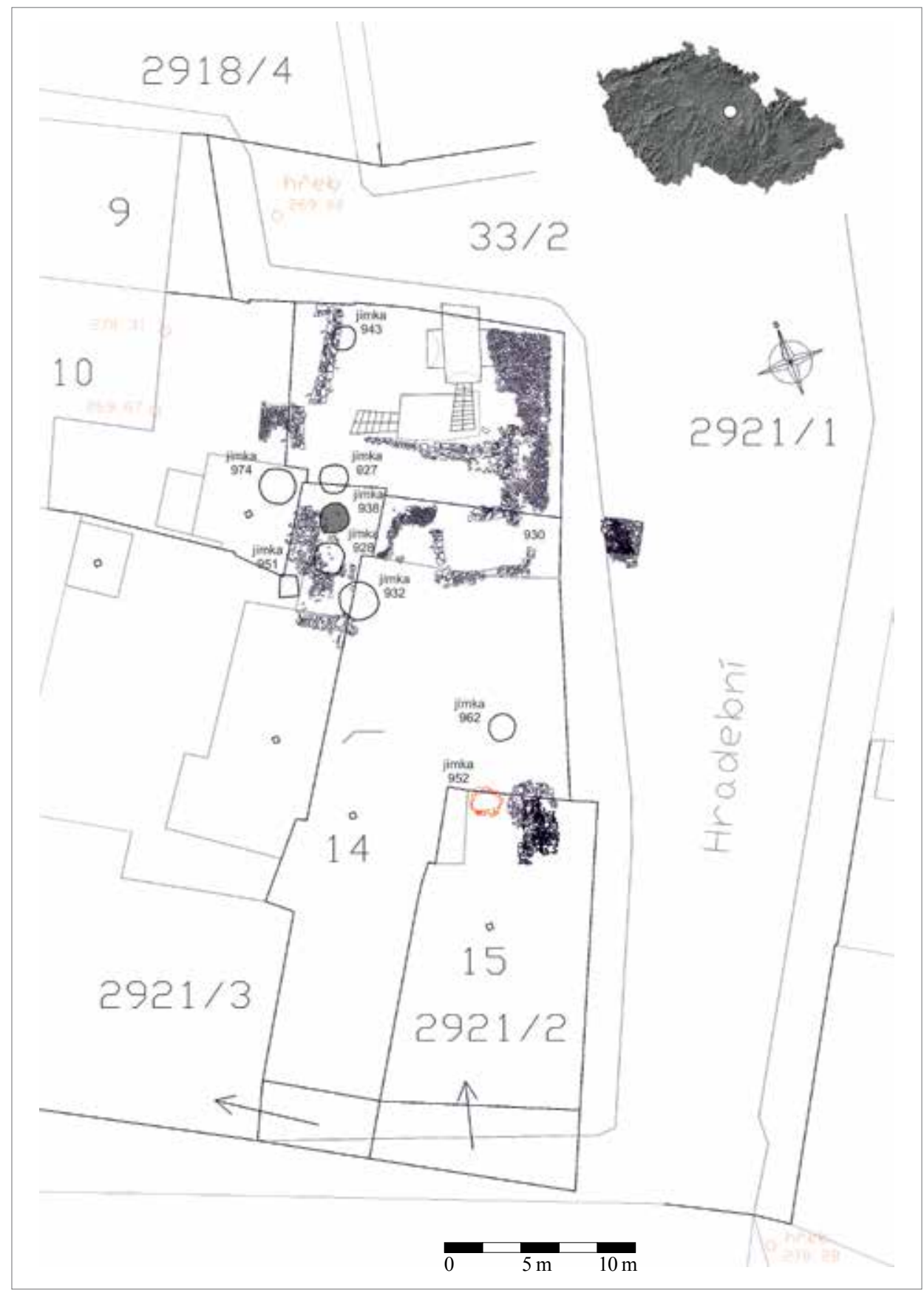

Obr. 1. Chrudim, Hradební ulice. Zkoumaná plocha s polohou objevených odpadních jímek a zděných stř̌edověkých konstrukcí. Jímka 938 zvýrazněna šedě. Podklad firma GEO.CZ, vyhotovil J. Musil.

Abb. 1. Chrudim, Hradební-Str. Untersuchte Fläche mit Lage der entdeckten Abwassergruben und mittelalterlichen Steinkonstruktionen. Grube 938 grau hervorgehoben. Unterlage Firma GEO.CZ, erstellt von J. Musil. 
úpravou stěn nebo obezděním z kamenů na sucho. Odpadní jámy (celkem čtyři) úpravu stěn postrádají. Chronologicky pokrývají období od přelomu 13. a 14. století do století osmnáctého. Zdá se, že po třicetileté válce byly na zkoumaných parcelách (tj. dvorcích domů čp. 10/I, 14/I a 15/I) hloubeny již jen odpadní jámy.

Nejvíce odpadních jímek spojujeme s parcelou domu čp. 14/I (celkem sedm jímek - jímky 927, 928A, 928B, 932, 938, 951 a 954). Prozkoumané jímky se nacházejí v severozápadní části dvorku především podél hranice s čp. 11/I. Jímky pokrývají období od přelomu 13. a 14. století (jímka 928B) až do století osmnáctého (jímky 932 a 938).

Všechny jímky i odpadní jámy byly zkoumány po přirozených vrstvách, což dovolilo sledovat detailně způsob jejich zaplňování. V jímkách se původně nacházel měkký nezkonsolidovaný zásyp, který se postupně sesedal, takže vytvářel charakteristické zvrstvení s uloženinami, jejichž okraje vybíhaly nahoru podél stěn jímky (řez uloženinou se podobá písmenu U). Měkký zásyp také bezesporu umožňoval, alespoň zpočátku, propadání těžších předmětů do starších uloženin. U některých jímek se podařilo doložit, že nad nimi zřejmě stála lehčí dřevěná stavba (prevét?). V nálezové situaci se to projevilo rozdělením plochy jímky na dvě části. Na jedné bylo zdokumentováno dláždění (nejčastěji z valounů), druhá byla prázdná. Navzájem je oddělovaly stopy dřeva nebo žlábek. Dlažba se prosedala do měkké výplně jímky a byla opakovaně nahrazována novou výdlažbou (v jímce 932 až pětinásobně - obr. 22). Postupné sesedání se mohlo odehrát až v intervalu dvou metrů. Sesedání obsahu se projevovalo velmi dlouho po vyřazení jímky z provozu. Obvykle tvořilo horní část výplně jímek mnohem mladší souvrství odlišného charakteru, často s nálezy 18. až 19. století (nap̌r. jímka 938). Některé jímky se jako mírné prolákliny projevovaly dokonce v recentní dlažbě překrývající dvorky až do zahájení výzkumu (jímka 973).

Naše pozornost se soustředí na odpadní jímku 938, situovanou uprostřed největší koncentrace jímek v severozápadním rohu dvorku náležejícího domu čp. 14/I (obr. 2). Severněji byla situována jímka 927, v těsném jižním sousedství se nacházela superpozice jímek 928A a 928B. Vzájemný stratigrafický vztah lze posoudit pouze s jímkou 928. Ta představuje superpozici starší vydřevené jímky 928B a mladší jímky $928 \mathrm{~A}$ oválně obezděné kamenem. Při hloubení jímky 938 byla jímka 928B narušena. Jímka 928A je stratigraficky mladší, ale jímku 938 nenarušila. Západně od jímky probíhá zed' 903, tvořící parcelní hranici. Jímka 938 tuto zed' (obdobně jako sousední jímky) respektuje, i když př́imý stratigrafický vztah dochován není.

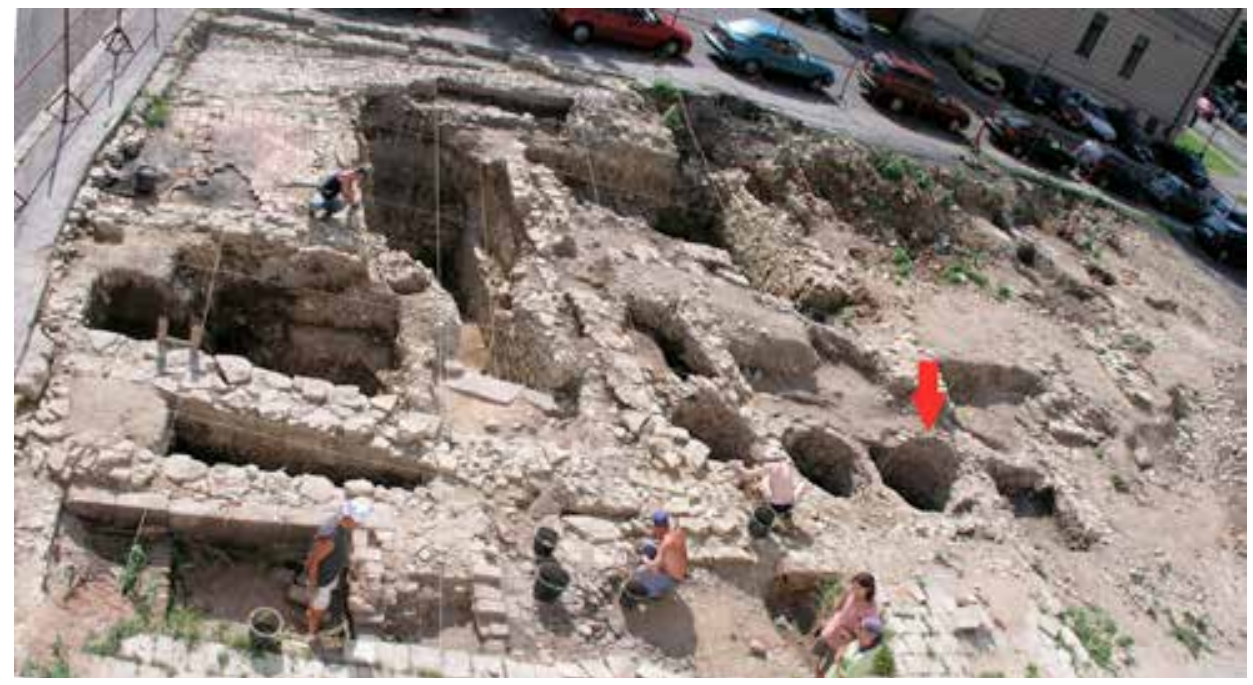

Obr. 2. Chrudim, Hradební ulice. Pohled na zkoumanou plochu. Šipka označuje jímku 938. Foto J. Frolík.

Abb. 2. Chrudim, Hradební-Str. Blick auf die untersuchte Fläche. Der Pfeil kennzeichnet Grube 938. Foto J. Frolík. 
Jímka byla dokumentována ve dvou vzájemně na sebe kolmých řezech, protože se nachází na rozhraní čtverců C2, C3, D2 a D3. Řez ve směru východ-západ (C2J - obr. 3) zachycuje průřez jímkou v úplnosti, řez kolmý (D2V) zachycuje zvrstvení jímky do hloubky pěti metrů, protože zužující se průměr jímky nedovolil dokumentovat nejnižší část uloženin. Některé uloženiny mají z technických důvodů dvojí označení (jedno pro čtverec $\mathrm{C} 2$ a druhé pro čtverec D2).

Jímka 938 je v půdorysu přibližně kruhová o průměru $1,7 \mathrm{~m}$. Válcovité těleso jímky je vyzděno z opukových kamenů, jímka byla hluboká $6,5 \mathrm{~m}$. Do hloubky přibližně $4,5 \mathrm{~m}$ má jímka stejný průměr, pak se postupně zužuje až na průměr $0,8 \mathrm{~m}$. Dno jímky je rovné a tvoří jej skalní podloží. Výplň jímky sestávala $\mathrm{z}$ hlinitých vrstev s př́měsí drobných kamenů, eventuálně malty či stavebního materiálu. Přibližně od hloubky 2 m nabývala výplň organičtějšího, zčásti fekálního charakteru, př́tomnost zlomků dřev byla registrována od hloubky $4 \mathrm{~m}$. Dřevo nebylo zachováno natolik, aby umožnilo identifikaci původního funkčního určení, a jeho stav nebyl vhodný ani pro použití dendrochronologie. Jímka se zaplňovala v souladu s výše uvedenými poznatky. Od tohoto schématu se odlišuje několik víceméně vodorovných vrstev, které představují předěl mezi uloženinami s prosedlým středem (uloženina D2/152; uloženiny D2/137 + D2/136 + D2/129 a C2/123 = D2/113). Domníváme se, že tyto vodorovné předěly vznikly při vybírání jímky. Odlišná je pouze horní část výplně jímky. Nad uloženinou C2/123 = D2/113 mají zbývající uloženiny téměř vodorovný průběh (v rozsahu C2/104 = D2/104 až C2/111 = D2/108). Tyto uloženiny obsahují větší příměs stavebního odpadu.

\section{Písemné prameny}

Konfrontace s dochovanými písemnými prameny přináší určité problémy. Zkoumané parcely a s nimi celý blok domů se nacházely ve čtvrti, která byla v soudobých písemných pramenech nazývána Klášterská, a to podle blízkého dominikánského kláštera situovaného v severovýchodním nároží městského areálu. Klášter zanikl za husitských válek, na jeho místě existovalo městské vězení, pravděpodobně využívající zbytků klášterních budov. Zánik kláštera následně znamenal změnu názvu čtvrti, dále byla označována jako Bohatá. Nejstarší písemné prameny pro Bohatou čtvrt' představují především městské knihy z 16. až 17. století, které se bohužel míjejí s chronologickým zařazením většiny archeologických situací. Domovní blok tvořilo v novověku sedm nemovitostí, připočteme-li zaniklý, archeologickým výzkumem objevený nárožní dům, pak osm. V době výzkumu stály pouze tři domy, a to samostatná čp. 9/I a 10/I. Původní čp. 11/I až 13/I byla sloučena v jeden celek.

Dům čp. 14/I nám svými nejstaršími zmínkami přibližuje události třicetileté války. Pojmenování zpustlého městiště upomíná na jinak neznámé majitele $(1641$ - „domu pustého slove Hodinovského“, 1668 - „domu pustého slove Formanovského“). Pustá byla parcela ještě v roce 1685, kdy místo pusté vedle Augustina Paumbergra, ,jdouc $k$ vězeni obecnímu v Bohaté čtvrti“, prodala obec za 4 kopy hotově Jindřichu Maršálkovi „tím oumyslem, aby vyzdvihnuto a jeden kontribuent přibýti mohl“. Jindřich Maršálek dům skutečně postavil, v roce 1709 byl oceněn na 180 zlatých. Maršálkové dům drželi až do roku 1735, kdy byl prodán za 440 zlatých Václavu Brozanskému i s vnitřním vybavením, které se konkrétně vyjmenovává: „stůl kulatý 1 , tabule dlouhé 3, stolic dlouhých 5, židliček 7, sesličky 2, španělské stěny 2, kuchyňská almara, šatní truhla zelená, 2 truhly pro suté obilí, 4 postele, 2 velké kádě $k$ várce, trychtéry spilací dřevèné 2 , sudy 3, 5 obrazů na plátně malovaných, mandl, šenktiš, hubatka 1, 10 džbánků skleněných“. Soupis vyjmenovává mimo jiné základní potřeby pro vaření piva a lze odvodit, že v domě byla hospoda. Další osudy této nemovitosti jsou sledem výměn a prodejů při pozvolna rostoucí ceně. Její existence se uzavřela $v$ roce 1994, kdy byla po poškození výbuchem plynu zbořena (historické údaje jsou převzaty z rukopisu Florián s. d.).

Písemné zprávy, byt' poměrně pozdní, však jednoznačně dokládají, jak velkým zásahem do městského života byla v Chrudimi třicetiletá válka. Z osmi domů sledovaného bloku zůstaly stát zřejmě jenom dva (čp. 11/I a 13/I). Zpustlá městiště prodávala obec jako svědectví toho, že původní majitelé bud' zahynuli, nebo nuceně emigrovali (čp. 11/I). Jeden z domů nebyl nikdy 


\section{$\mathrm{C} 2 \mathrm{~J}$}

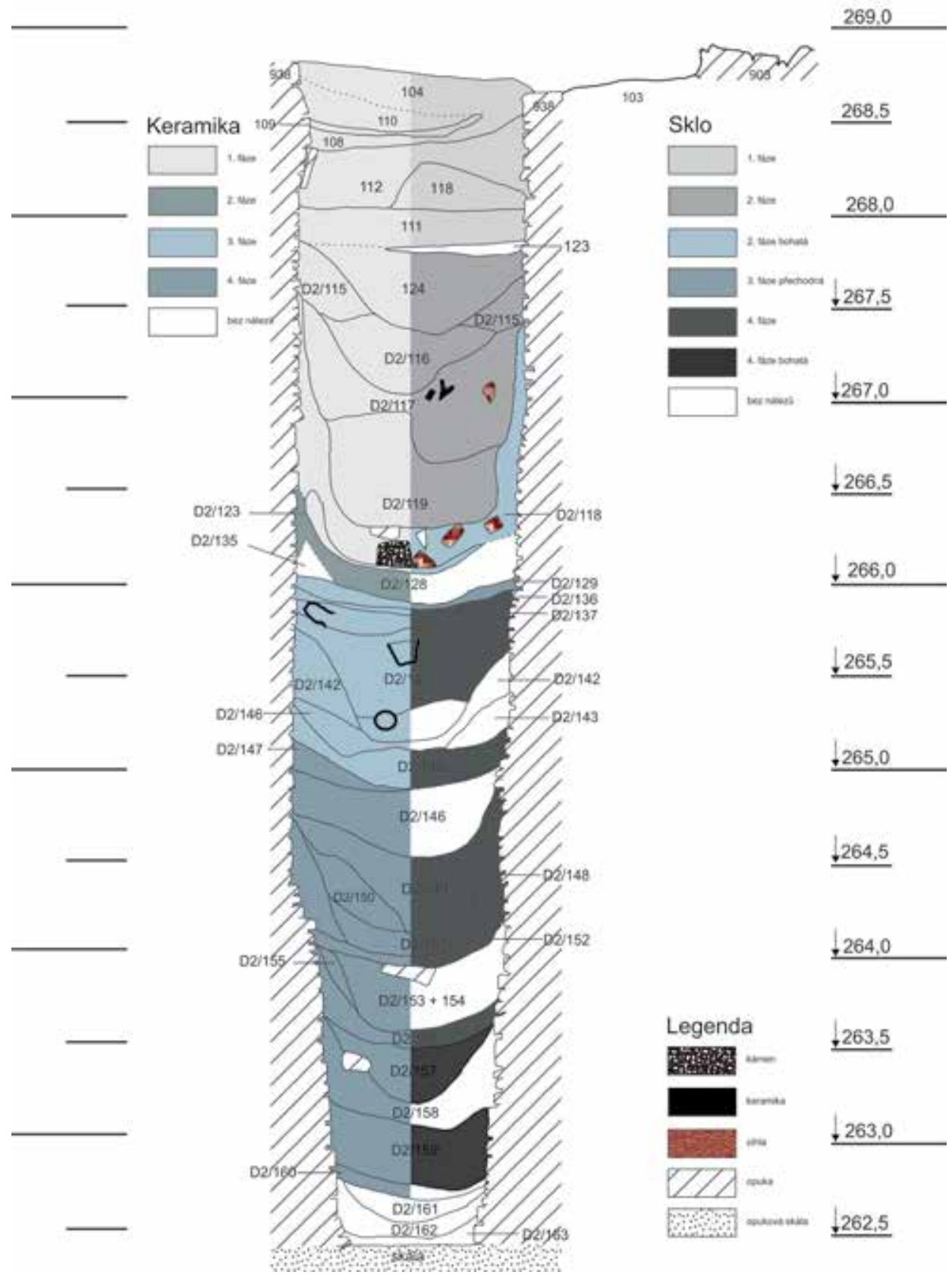

Obr. 3. Chrudim, Hradební ulice, jímka 938. Řez C2J s rozdělením podle jednotlivých horizontů, vlevo keramika, vpravo sklo. Chronologické zařazení jednotlivých horizontů v textu. Kresba J. Musil.

Abb. 3. Chrudim, Hradební-Str., Grube 938. Schnitt C2J mit Verteilung gemäß den einzelnen Horizonten, links Keramik, rechts Glas. Chronologische Einordnung der einzelnen Horizonte im Text. Zeichnung J. Musil. 
obnoven a jeho pozemek byl přičleněn k čp. 10/I. Obnova nemovitostí se protáhla na několik desetiletí (jako poslední dům čp. 15/I po roce 1711). Ve zkoumaných jímkách s tímto a mladším obdobím souvisí pouze ta část výplně, která vyrovnávala depresi po starších slehlých vrstvách.

\section{Nálezy}

\subsection{Keramika}

Při rozboru keramiky z jímky 938 byly vymezeny celkem čtyři výrazné časové a technologicky odlišné horizonty (označené barvami - obr. 3). Svrchní horizont (označený 1. fáze) obsahující uloženiny (odshora: C2/104, C2/110, C2/109, C2/108, C2/112, C2/118, C2/111, C2/123, C2/124, D2/115, D2/116, D2/117, D2/119, D2/118 a D2/123) je datován dle nalezených keramických zlomků do 17.-18. století. V horních partiích je keramika více fragmentarizovaná, chronologicky často velmi nesourodá, výplně jímky se blíží charakterem přemístěné suti. Zhruba od úrovně uloženiny D2/115 se setkáváme s méně fragmentarizovaným keramickým souborem. Keramika je převážně oxidačně pálená, na lomu se střepem bělošedé, oranžové a žlutookrové barvy. Keramické zboži je částečně opatřeno převážně transparentními žlutými, hnědými, žlutozelenými a zelenými polevami, poprŕípadě jejich kombinacemi. Základní keramické tvary (obr. 4:1,2) představují různé velikostní varianty hrnce s uchem, dále džbány, talírovité mísy, trojnožky ad. (k přerodu pozdně středověké do tzv. lidové keramiky viz Durdík 1980, 361-368; Pajer 1982; 1983; 2001; Scheufler 1963; 1972; Vařeka 1998, 123-137; 2002, 217-250; Zápotocký 1978; 1979; pro sousední země - např. Hoššo 2004, 569-580; Kohlprath 1982; Bauer a kol. 1986; Kruppé 1981). V případě talířovitých mís se setkáváme s užitím malovaného dekoru pomocí kukačky. Významnou část tohoto horizontu tvoří majolikové talířovité mísy (obr. 5:1,2) částečně domácí produkce (Scheufler 1972). Výraznou složkou jsou zlomky modré talířovité mísy z okruhu jindřichohradecké mezzomajoliky (obr. 6:3 - Scheufler 1972; Scheufler-Štajnochr-Turnský 1974; Štajnochr 1990; 1992; 1998; Štajnochr-Fröhlich-Krajíc-Militký 1998, 445-468; Fröhlich 2015). Jednoznačně cizí složku představují jihoněmecké fajánse kopírující orientální dekor (obr. 6:1, 2, 4 - Riesebieter 1921, Abb. 159). Analogickou výzdobu registrujeme v Chrudimi i v souboru keramiky z odpadní jámy za čp. 26/I ve Filištínské ulici. Luxusní zboží je dále zastoupeno zlomky mužakovské kameniny (obr. 5:3, 4) ${ }^{1}$ a jejích četných domácích napodobenin (obr. 5:5, 6 a 6:5 - k mužakovské kamenině Horschik 1978, 295-364; k napodobování v domácí produkci Scheufler 1972, 52-53, 57-60, 62). Mezi zvláštní tvary objevené v rámci tohoto horizontu patří torzo keramické plastiky (?) (obr. 5:10), zlomek keramického zvonku (obr. 5:7), formička na výrobu antropomorfních aplikací při výrobě kamnových kachlů (obr. 5:11), ${ }^{2}$ ucho drobné stolní nádobky ve tvaru lidské hlavičky (obr. 5:8) a zlomek zeleně glazované troubele dýmky slezské provenience (Musil 2008; 2010, 524, č. kat. 13 - obr. 5:9). Z uloženiny D2/118 byly získány i nádobkové kachle s pravoúhlým ústím a slídovým přetahem datovatelné do první poloviny 16. století (obr. 4:3, 4 - srov. Frolík 2003, 16, č. kat. 5).

Změna ve složení keramického souboru byla registrována na úrovni uloženiny D2/128, kde byl vymezen přechodný horizont (2. fáze) datovaný do 16.-17. století. Zde se ještě v menší míře uplatňovalo režné redukční keramické zboží (snad z ledečského, jihočeského či jihomoravského, popř. čáslavského okruhu), nicméně většina keramiky náležela oxidačně pálenému, částečně transparentně glazovanému zboží, na lomu se střepem bělošedé a oranžové barvy, krytému na vnitřní straně nádoby hnědočervenou či žlutooranžovou transparentní glazurou - zboží typu Husova ulice (Frolík-Sigl 1990; k nastupující raně novověké produkci v Chrudimi Musil 2010a, 21-36). Základní keramické tvary představují různé velikostní varianty hrnce (obr. 7:1). Z vrstvy byly mimo jiné získány i nádobkové kachle s pravoúhlým ústím (obr. 7:2) a zlomky kachle

\footnotetext{
1 Produkční zóna se nalézala v Bad Muskau v Horní Lužici (Sasko, Kr. Görlitz).

2 Kachle, které byly vytvářeny pomocí této formy, byly nalezeny při výkopových pracích na hradě Košumberku v roce 1922 (Frolík-Musil 2016, obr. 58:1). Dalši zlomky forem na výrobu kachlů byly získány i z výplně odpadní jámy 501 na sousední parcele. Je tedy zřejmé, že zlomek objevený v jímce 938 se do ní dostal druhotně.
} 

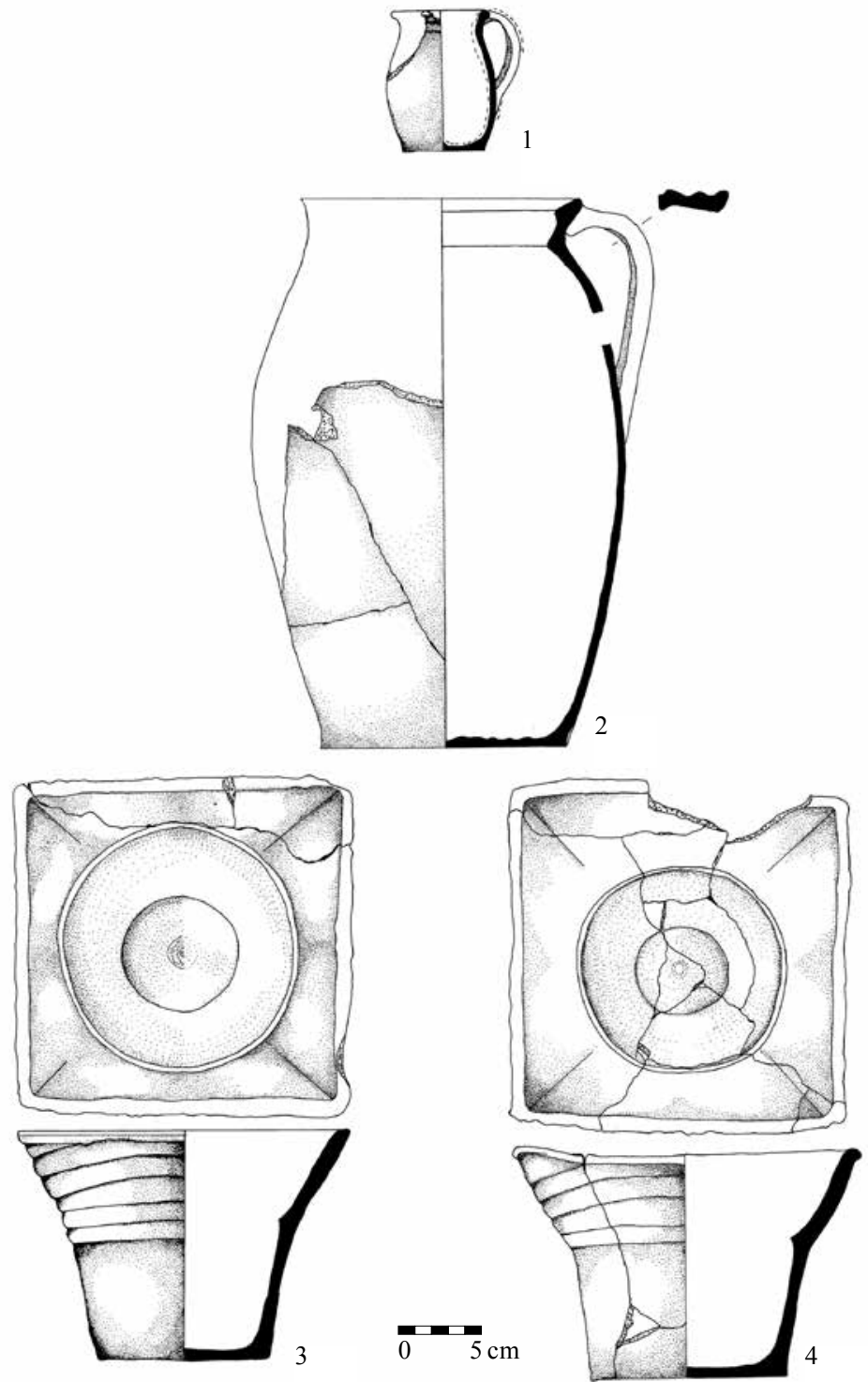

Obr. 4. Chrudim, Hradební ulice, jímka 938, řez C2J. První fáze, keramika. 1 - miniaturní nádobka, inv. č. A31455, k. D2/123; 2 - hrnec, inv. č. A31481, k. D2/123; 3 - nádobkový kachel, inv. č. A31406, k. D2/118; 4 - nádobkový kachel, inv. č. A 31353, k. D2/118. Kresba B. Hlaváčová.

Abb. 4. Chrudim, Hradební-Str., Grube 938, Schnitt C2J. Erste Phase, Keramik. 1 - Miniaturgefäß, Inv.-Nr. A31455, Kontext D2/123; 2 - Topf, Inv.-Nr. A31481, Kontext D2/123; 3 - Topfkachel, Inv.-Nr. A31406, Kontext D2/118; 4 - Topfkachel, Inv.-Nr. A 31353, Kontext D2/118. Zeichnung B. Hlaváčová.

s pozdně gotickým majuskulním nápisem „PANE...“( (obr. 7:3). Tato varianta nápisového kachle nebyla doposud na Chrudimsku registrována (Frolík 2003).

Z uloženiny D2/135 nebyly získány žádné keramické fragmenty. Do období vrcholného rozkvětu města, tedy do druhé poloviny 15 . až poloviny 16 . století, je řazen horizont označený 

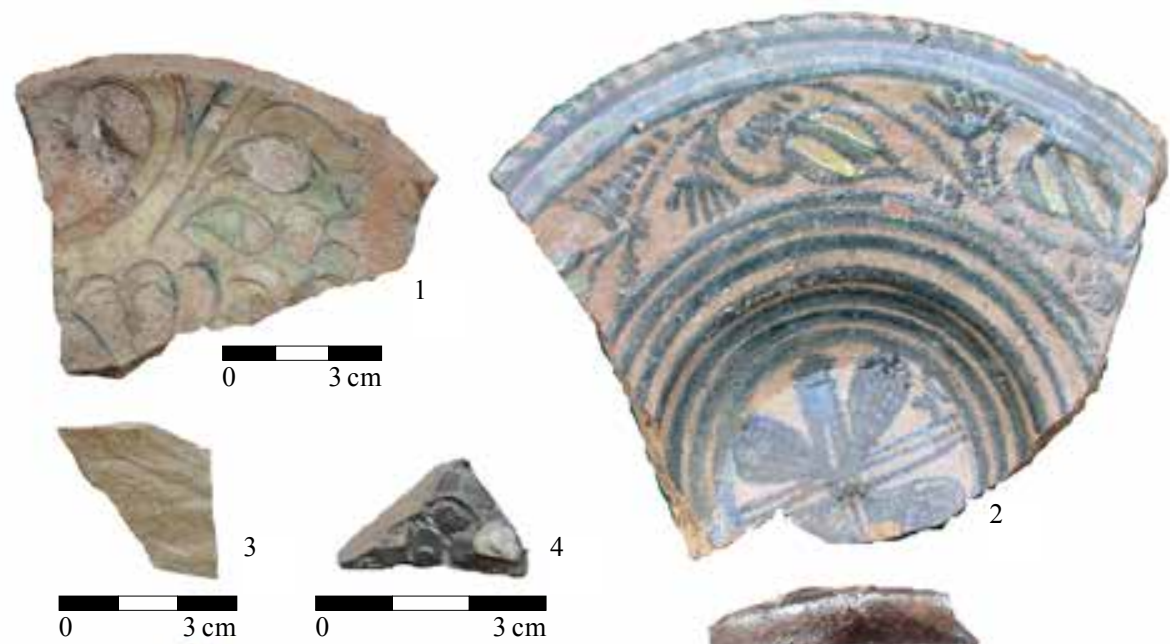

$3 \mathrm{~cm}$

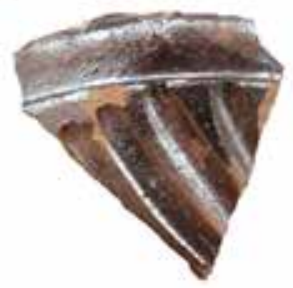

6

5
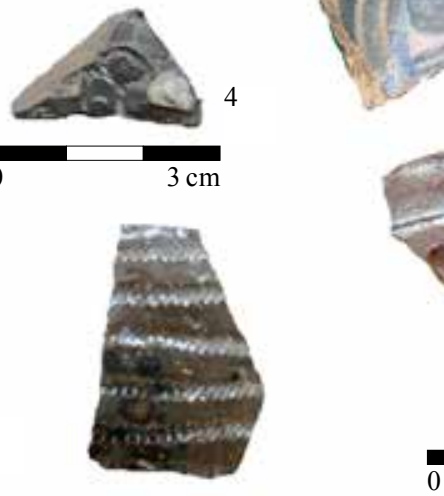

$3 \mathrm{~cm}$

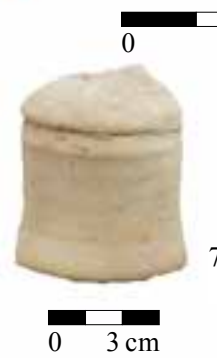

$3 \mathrm{~cm}$

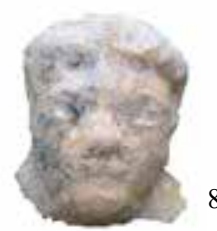

8
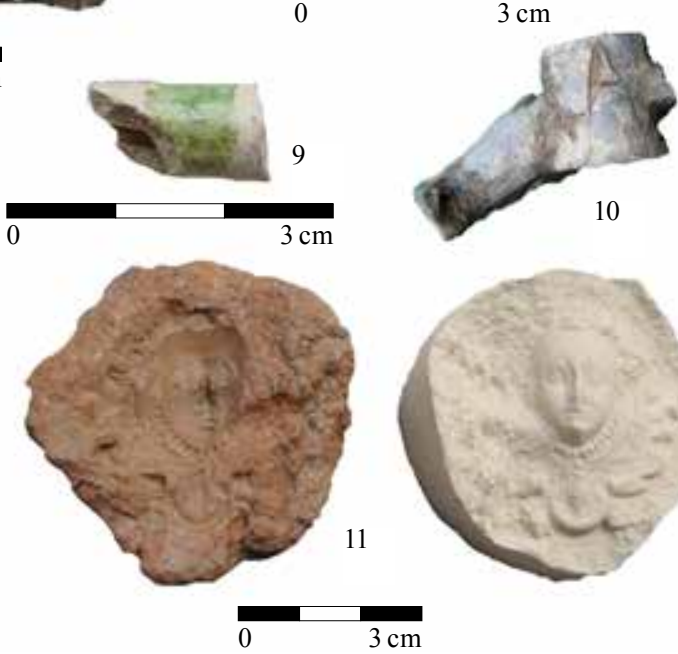

7

0

Obr. 5. Chrudim, Hradební ulice, jímka 938, řez C2J. První fáze, keramika. 1 - mezzomajolika, inv. č. A31230, k. D2/105; 2 - majolika, inv. č. A31402, k. D2/118; 3 - kamenina, inv. č. A30646, k. D2/110; 4 - mužakovská kamenina, inv. č. A31020, k. D2/116; 5 - napodobenina mužakovské kameniny, inv. č. A31020, k. D2/116; 6 - napodobenina mužakovské kameniny, inv. č. A30783, k. D2/114; 7 - zlomek keramického zvonku, inv. č. A30783, k. D2/114; 8 - zlomek ucha, inv. č. A31419, k. D2/118; 9 - zlomek troubele dýmky, inv. č. A30823, k. D2/114; 10 - keramický předmět, inv. č. A31368, k. D2/123; 11 - keramická formička, inv. č. A30669, k. C2/108. Foto J. Frolík, J. Musil a S. Vylíčilová.

Abb. 5. Chrudim, Hradební-Str., Grube 938, Schnitt C2J. Erste Phase, Keramik. 1 - Mezzomajolika, Inv.-Nr. A31230, Kontext D2/105; 2 - Majolika, Inv.-Nr. A31402, Kontext D2/118; 3 - Steinzeug, Inv.-Nr. A30646, Kontext D2/110; 4 - Muskauer Steinzeug, Inv.-Nr. A31020, Kontext D2/116; 5 - Imitation von Muskauer Steinzeug, Inv.-Nr. A31020, Kontext D2/116; 6 Imitation von Muskauer Steinzeug, Inv.-Nr. A30783, Kontext D2/114; 7 - Fragment einer Keramikglocke, Inv.-Nr. A30783, Kontext D2/114; 8 - Henkelfragment, Inv.-Nr. A31419, Kontext D2/118; 9 - Bruchstück eines Pfeifenholms, Inv.-Nr. A30823, Kontext D2/114; 10 - Keramikgegenstand, Inv.-Nr. A31368, Kontext D2/123; 11 - kleine Keramikform, Inv.-Nr. A30669, Kontext C2/108. Foto J. Frolík, J. Musil und S. Vylíčilová. 

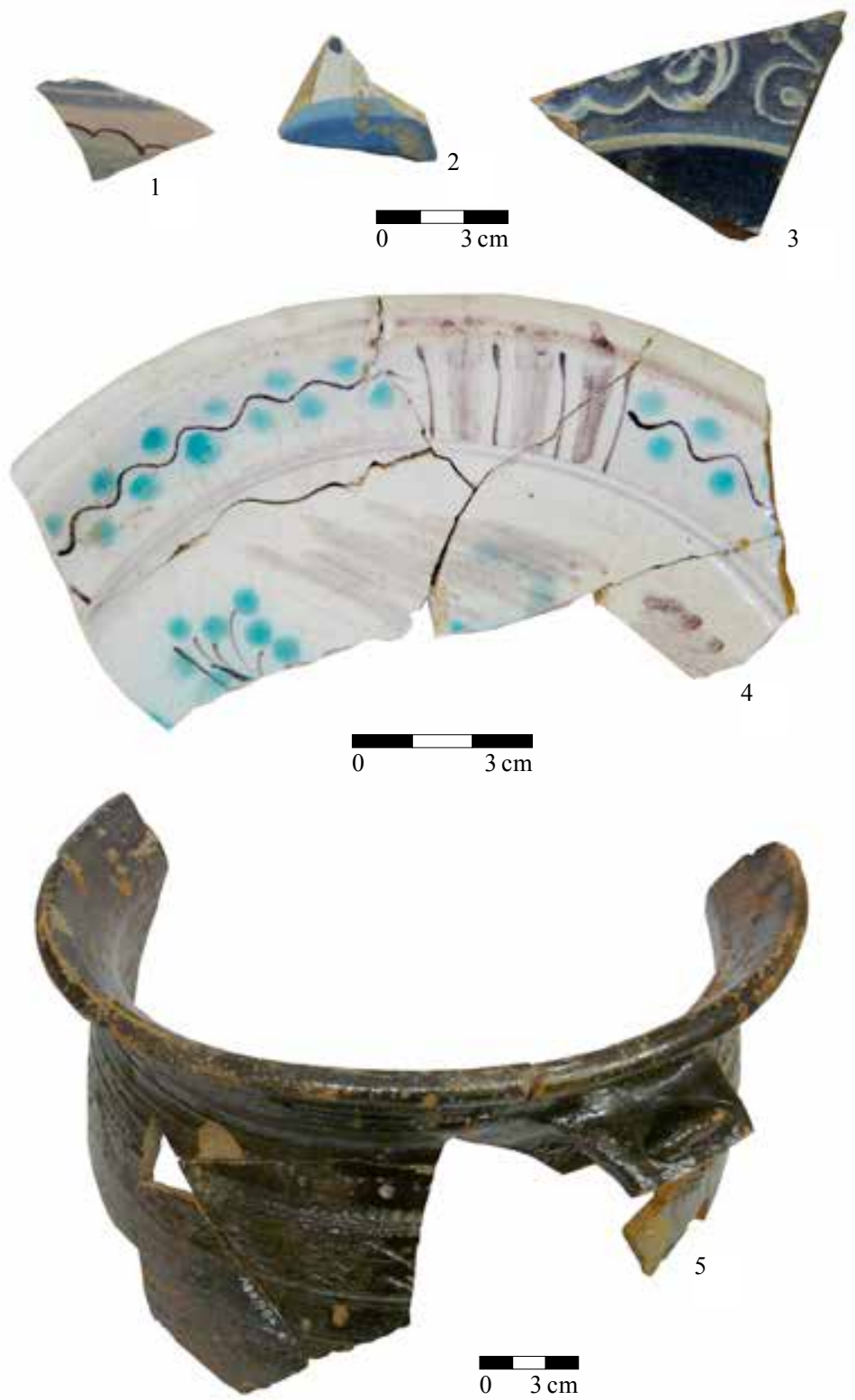

Obr. 6. Chrudim, Hradební ulice, jímka 938, řez C2J. První fáze, keramika. 1 a 2 - jihoněmecká fajáns, inv. č. A30600, k. D2/110; 3 - jindř̌ichohradecká mezzomajolika, inv. č. A30600, k. D2/110; 4 -jihoněmecká fajáns, inv. č. A30726, k. D2/108; 5 - napodobenina mužakovské kameniny, inv. č. A30704 a A30726, k. D2/108. Foto J. Frolík, J. Musil a S. Vylíčilová.

Abb. 6. Chrudim, Hradební-Str., Grube 938, Schnitt C2J. Erste Phase, Keramik. 1 und 2 - süddeutsche Fayance, Inv.-Nr. A30600, Kontext D2/110; 3 - Neuhauser Mezzomajolika, Inv.-Nr. A30600, Kontext D2/110; 4 - süddeutsche Fayance, Inv.-Nr. A30726, Kontext D2/108; 5 - Imitation von Muskauer Steinzeug, Inv.-Nr. A30704 und A30726, Kontext D2/108. Foto J. Frolík, J. Musil und S. Vylíčilová. 

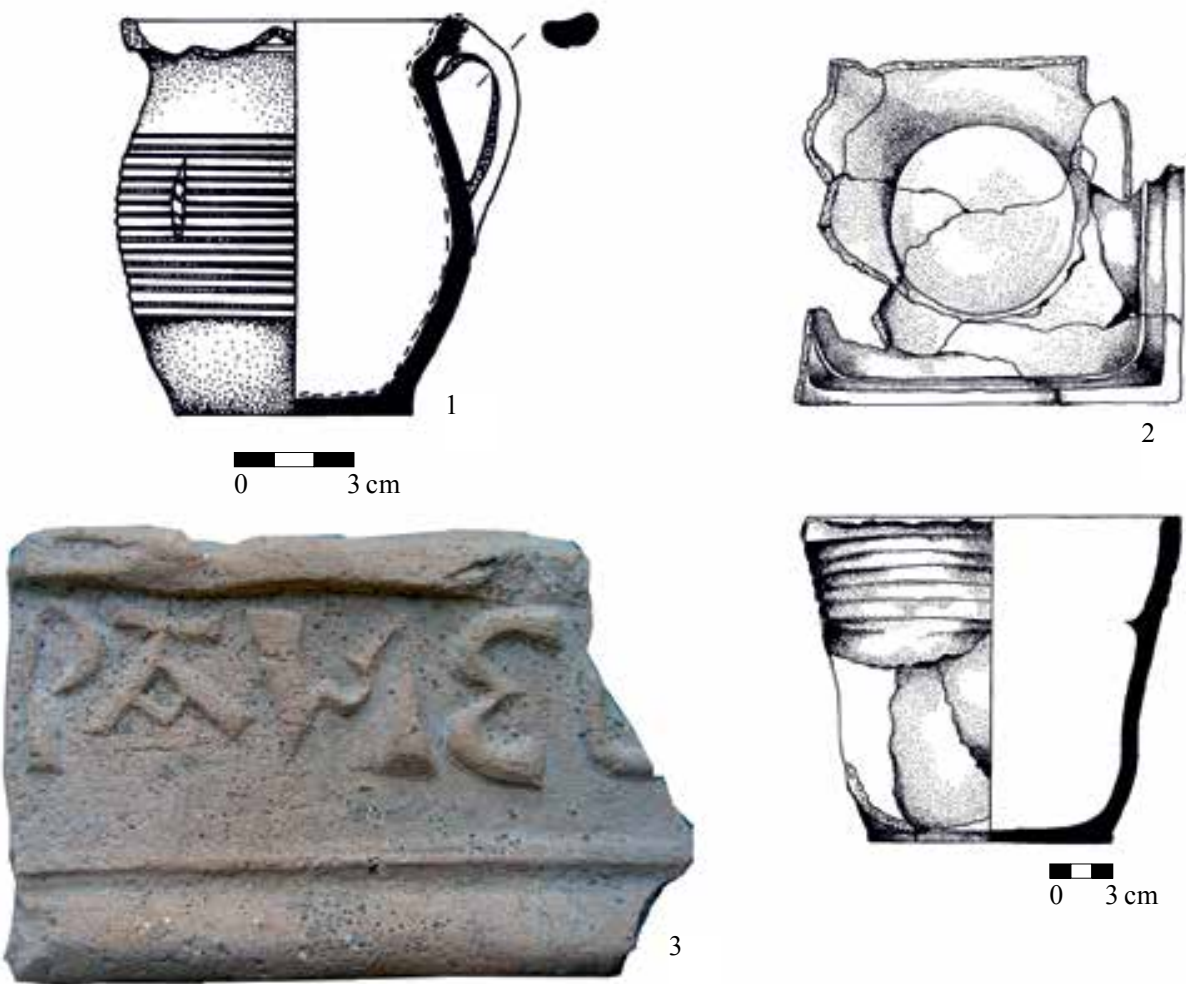

Obr. 7. Chrudim, Hradební ulice, jímka 938. Řez C2J. Druhá fáze, keramika. 1 - hrnec, inv. č. A31518; 2 - nádobkový kachel s pravoúhlým ústím, inv. č. A31526; 3 - zlomek čelní stěny komorového kachle s nápisem „PANE“, inv. č. A31519. V̌̌e kontext C2/142 = D2/128. Kresba B. Hlaváčová.

Abb. 7. Chrudim, Hradební-Str., Grube 938. Schnitt C2J. Zweite Phase, Keramik. 1 - Topf, Inv.-Nr. A31518; 2 - Topfkachel mit Rechteckmündung, Inv.-Nr. A31526; 3 - Fragment der Schauseite einer Blattkachel mit Inschrift „PANE“, Inv.-Nr. A31519. Alles Kontext C2/142 = D2/128. Zeichnung B. Hlaváčová.

jako 3. fáze jímky 938, který obsahuje uloženiny (odshora: D2/129, D2/136, D2/137, D2/141, D2/144, D2/142, D2/143 a D2/145). Podobně jako na nedalekém hradě Rabštejnku (Musil 2009) se i zde vyskytuje souběžně šedé redukční zboží zdobené radélkem, hnědočerveně glazované zboží typu Husova ulice a keramika severomoravského výrobního okruhu. Skladba keramických skupin v tomto časovém období je podobná i na jiných místech regionu (hrady Košumberk, Oheb, Žumberk, Nové Hrady ad.) a jejímu studiu bude v budoucnu věnována značná pozornost. V rámci 3. fáze dominuje režné redukční keramické zboží většinou zdobené pomocí radélka z produkčních oblastí ledečské, jihočeské a jihomoravské (Pfaffenschlag - Nekuda 1975; Mstěnice - Nekuda 1985; 1997; Ledeč nad Sázavou - Nechvátal 1967; Chvátal-Rous-Vokáč-Zimola 2013). ${ }^{3}$ Významnou, i když početně mnohem méně zastoupenou složkou je režné oxidační velmi tvrdě pálené místní zboží s charakteristickými tzv. chrudimskými poháry (obr. 8). Výraznou skupinu keramiky nastupující raně novověké hrnčiny představuje místní oxidační hnědočerveně transparentně částečně glazované zboží typu Husova ulice (Frolík-Sigl 1990). Mezi zajímavé importy patř́i červená oxidačně pálená keramika zdobená radélkem a bílým malováním. Malba je velmi sprašná a špatně se uchovává. Keramika s bíle malovaným dekorem se vyskytuje

3 Z roku 1486 máme doklad prodeje výrobků z Loštic a Ledče nad Sázavou na chrudimském trhu (Nekuda-Reichertová 1968, 25; Goš 2007, 96). 
zejména ve středočeském prostoru, odkud zasahuje do přilehlých regionů. Poprvé se ve středočeském prostoru vyskytuje ve 13. století (Durdík 1983, 211-213), nicméně zlomky objevené v Chrudimi náležejí mladšímu horizontu jejího výskytu. Na Klučově její výskyt spadá do 20.-30. let 15. století (Kudrnáč 1973, 119), soubor z jeskyně Mincovna u Koněprus do prvních dvou desetiletí druhé poloviny 15. století (Hejna-Radoměrský 1958, 532). Keramika ze zaniklé středověké vsi Oujezda je datována k polovině 15. století, nálezy z Anežského kláštera v Praze (Reichertová 1968) a z Libice nad Cidlinou (Hazlbauer-Špaček 1987, 31) se hlásí do 15. století. Keramický soubor ze zaniklé středověké vsi Vesce a z Čelákovic náleží do poloviny 16. století. Podobně je datována i keramika z Cukmantlu, Litoměřic a Turnova-Sokolova (Hazlbauer-Špaček 1987, 44). Vzhledem k dominanci redukčního zboží se Chrudimsko výrazně odlišuje například od Hradce Králové a severovýchodočeské oblasti, kde naopak dominuje oxidační světlé zboží. ${ }^{4}$ Základní keramické tvary představují různé velikostní varianty hrnců s uchem i bez něj s maximální výdutí v horní třetině nádoby (obr. 9), džbány (obr. 10), poháry (obr. 8), mísy s výlevkou (obr. 11:2) i prototypy novověkých tzv. koutních mís s jedním či dvěma třmenovými uchy (obr. 11:4), trojnožky s rozevřenou tulejí a pokličky (obr. 11:1). Nálezy doplňují ještě nádobkové kachle s pravoúhlým ústím, přičemž u některých exemplářů je vnitřní obvodová lišta př́ejeta radélkem (obr. 11:3, obr. 12).

Pro poslední dva metry výplní jímky 938 byl vymezen horizont, označený jako 4. fáze, datovaný nálezy keramiky do druhé poloviny 14 . století až první poloviny 15 . století. Tento horizont sestává z uloženin (odshora: D2/147, D2/146, D2/149, D2/150, D2/151, D2/148, D2/152, D2/153 + 154, D2/155, D2/156, D2/157, D2/158, D2/159 a D2/160). Obecně lze říci, že v keramickém materiálu zejména na úrovni uloženin D2/147, D2/146 a D2/149 je patrný přísun luxusnější importované keramiky (loštická - obr. 13:5-7 a glazovaná - obr. 14:1), navýšení počtu pohárů (obr. 13) a džbánů (obr. 14). Tento jev je sledovatelný i na jiných místech v Chrudimi (Filištínská ul.: jímky VIIA, VIIB a X - Wolf 2002; obecně sonda H - Horák 2007; jímka XIXB - Sehnoutková 2011), nicméně nikoliv v takovém množství jako v Hradební ulici. Rovněž sledujeme někdy v tomto období přísun redukční kovově lesklé keramiky do původní zóny s oxidačně vypalovanou keramikou. ${ }^{5}$ Nejlépe datovatelné a rozpoznatelné je zboží severomoravského výrobního okruhu s typickými zásobními hrnci (obr. 11:6) ${ }^{6}$ a charakteristickými loštickými poháry. V rámci tohoto horizontu byl objeven loštický pohár typu IA dle tř́idění Z. Měřínského (1969, 90 - obr. 13:5), který by náležel do 3. fáze severomoravského výrobního okruhu (Goš 2007, 90, obr. 37).

Specifickou skupinou je bílé červeně malované zboží, které bylo současně vyráběno na různých místech České republiky (Gabriel-Smetana 1983). Pro starší období je typickým tvarem soudkovitý hrnec s uchem s ovaleným okrajem a s tělem zdobeným vývalkovou šroubovicí (obr. $15: 2-5,8,13)$ a hrnec $\mathrm{s}$ uchem s okrajem provedeným ve formě nepravého silně ven vyhnutého okruží. Od posledně zmiňované varianty hrnce vede přímá vývojová linie k tzv. chrudimskému poháru (obr. 13:8-11). ${ }^{8}$ Technologicky je zboží při bázi jímky ještě opatřeno značkami na dně,

\footnotetext{
4 Pozdně středověká keramika v Hradci Králové není doposud komplexně zpracována (Richter-Vokolek 1998). Radélko, většinou v podobě křižků, se vyskytuje na světlé oxidační keramice, která v souborech konce 15. až 16. století dominuje. Za tuto informaci vděčíme R. Bláhovi z Muzea východních Čech v Hradci Králové. Shodná situace je v př́ípadě severovýchodočeského hradu Vízmburka, který zanikl v roce 1447 (Soukup 2003, 31; Koštál 2007). Na Pražském hradě v jímkách u domu zbrojního písaře v období 16.-17. století tvořila oxidační glazovaná keramika 58,7\%, zatímco režná šedá redukční jen 14,2\% (Blažková-Dubská 2007, 17).

5 Distribuční zóny vymezené P. Vařekou (1998, obr. 1). Podle něj sever našeho území zaujímá oxidační tvrdě pálená keramika, jih šedá redukční a pruh mezi nimi tvoři hrubá středně tvrdě oxidačně pálená keramika. V tomto pásmu by se měla podle P. Vařeky nalézat ještě Č́slav a přilehlá východní část středních Čech (Vařeka 1998, 132).

6 Zásobní hrnce podle V. Goše $(2007,64)$ se objevují v závěru 14. století, největšího rozmachu dosahují v první polovině 15 . století a po roce 1450 by se měly vytrácet. $\mathrm{S}$ tím zcela nekorespondují písemné zprávy - srovnej pozn. 3 .

7 Viz pozn. 3.

8 Písemně jsou hrnčíri v Chrudimi opakovaně doloženi až po roce 1465 společně s dalšími řemesly. Zlomek berního rejstříku z let $1399-1402$ uvádí pouze čtyři (Vojtíšek 2016), ale je možné, že další byli přičleněni k živnostem pracujícím s ohněm, podobně jako je tomu i v nedaleké Čáslavi. Jasný důkaz existence hrnčířské dílny podaly archeologické výzkumy v Husově ulici, kde byly mimo jiné nalezeny i polotovary a výrobní zmetky (Frolík-Sigl 1990), a výzkum na Masarykově náměstí před hotelem Bohemia, kde byly nalezeny hrnčířské podložky (kredle - Musil 2015). Zvláštní kapitolou je hrnčiřský mistr Jan Medek, který je v městských knihách výslovně zmiňován mezi lety $1512-1538$ (Frolík-Hazlbauer-Rückerová 1995 - vlastně jen náhodná sonda do starších archivních pramenů). Absence většího počtu písemných zmínek o hrnčiřském řemesle v období před rokem 1465 nekoresponduje se svědectvím archeologických pramenů.
} 

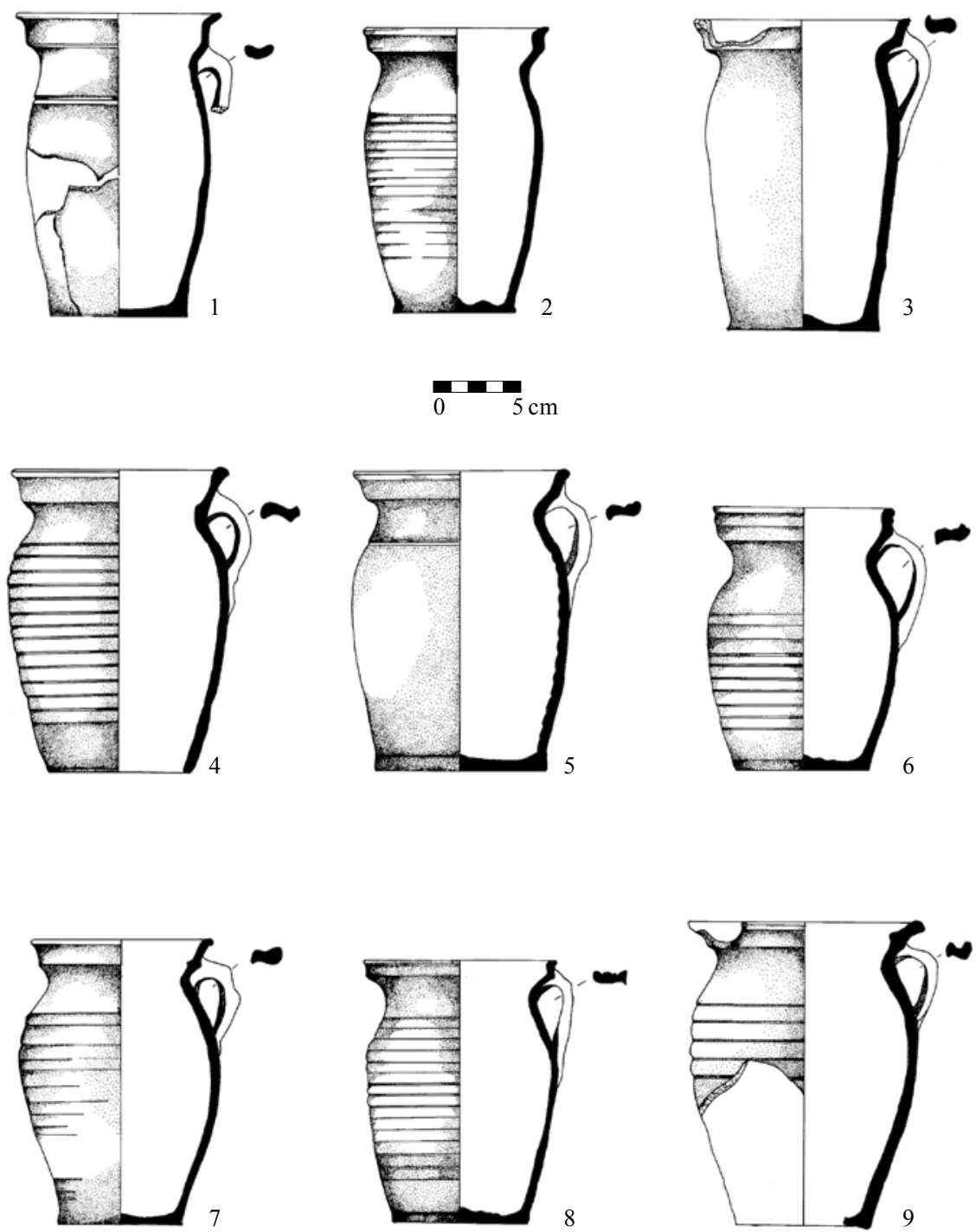

Obr. 8. Chrudim, Hradební ulice, jímka 938, řez C2J. Třetí fáze, tzv. chrudimské poháry. 1 - inv. č. A31734, k. D2/142; 2 - inv. č. A31782, k. D2/144; 3 - inv. č. A31708, k. D2/141; 4 - inv. č. A31710, k. D2/141; 5 - inv. č. A31709, k. D2/141; 6 - inv. č. A31790, k. D2/142; 7 - inv. č. A31784, k. D2/145; 8 -inv. č. A31851; 9 - inv. č. A31786, k. D2/145. Kresba B. Hlaváčová. Abb. 8. Chrudim, Hradební-Str., Grube 938, Schnitt C2J. Dritte Phase, sog. Chrudimer Becher. 1 - Inv.-Nr. A31734, Kontext D2/142; 2 - Inv.-Nr. A31782, Kontext D2/144; 3 - Inv.-Nr. A31708, Kontext D2/141; 4 - Inv.-Nr. A31710, Kontext D2/141; 5 - Inv.-Nr. A31709, Kontext D2/141; 6 - Inv.-Nr. A31790, Kontext D2/142; 7 - Inv.-Nr. A31784, Kontext D2/145; 8 - Inv.-Nr. A31851; 9 - Inv.-Nr. A31786, Kontext D2/145. Zeichnung B. Hlaváčová. 

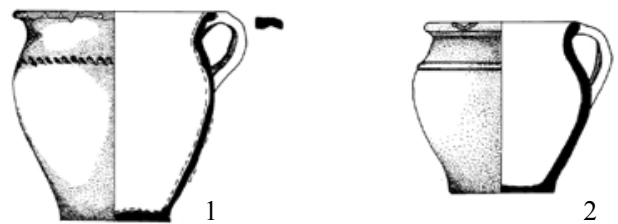

2
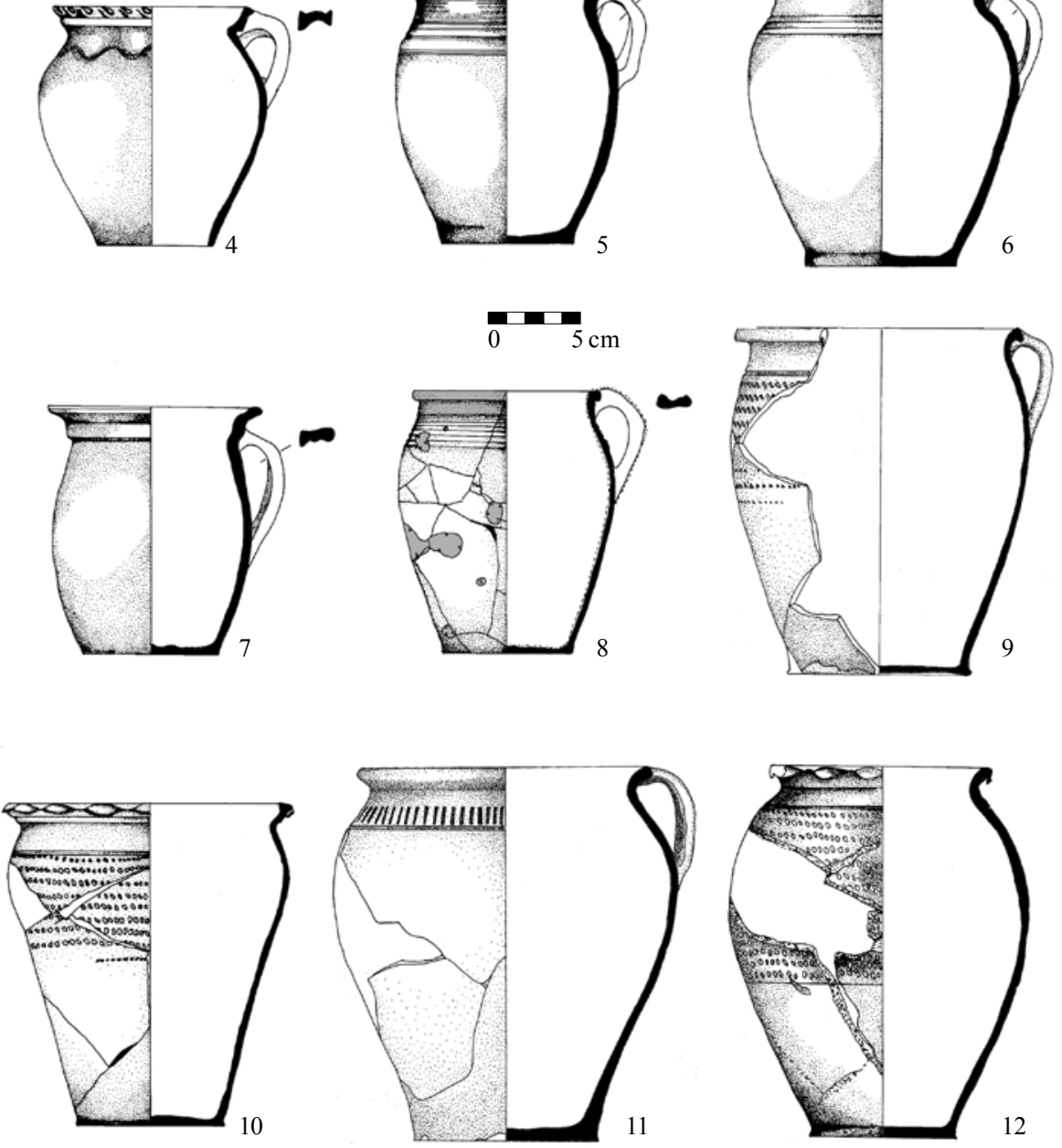

Obr. 9. Chrudim, Hradební ulice, jímka 938, řez C2J. Třetí fáze, výběr hrncovitých nádob. 1 - inv. č. A31611, k. D2/137; 2 - inv. č. A31715, k. D2/141; 3 - inv. č. A31789, k. D2/145; 4 - inv. č. A31714, k. D2/141; 5 - inv. č. A31682, k. D2/141; 6 inv. č. A31791, k. D2/142; 7 - inv. č. A31792, k. D2/142; 8 - inv. č. A31902, k. D2/144; 9 - inv. č. A31737, A31697 a A31701, k. D2/141; 10 - inv. č. A31697 a A31734, k. D2/142; 11 - inv. č. A31734, k. D2/142; 12 - inv. č. A31697 a A31734, k. D2/142. Kresba B. Hlaváčová a P. Dudková.

Abb. 9. Chrudim, Hradební-Str., Grube 938, Schnitt C2J. Dritte Phase, Auswahl topfartiger Gefäße. 1 - Inv.-Nr. A31611, Kontext D2/137; 2 - Inv.-Nr. A31715, Kontext D2/141; 3 - Inv.-Nr. A31789, Kontext D2/145; 4 - Inv.-Nr. A31714, Kontext D2/141; 5 - Inv.-Nr. A31682, Kontext D2/141; 6 - Inv.-Nr. A31791, Kontext D2/142; 7 - Inv.-Nr. A31792, Kontext D2/142; 8 - Inv.-Nr. A31902, Kontext D2/144; 9 - Inv.-Nr. A31737, A31697 und A31701, Kontext D2/141; 10 - Inv.-Nr. A31697 und A31734, Kontext D2/142; 11 - Inv.-Nr. A31734, Kontext D2/142; 12 - Inv.-Nr. A31697 und A31734, Kontext D2/142. Zeichnung B. Hlaváčová und P. Dudková. 

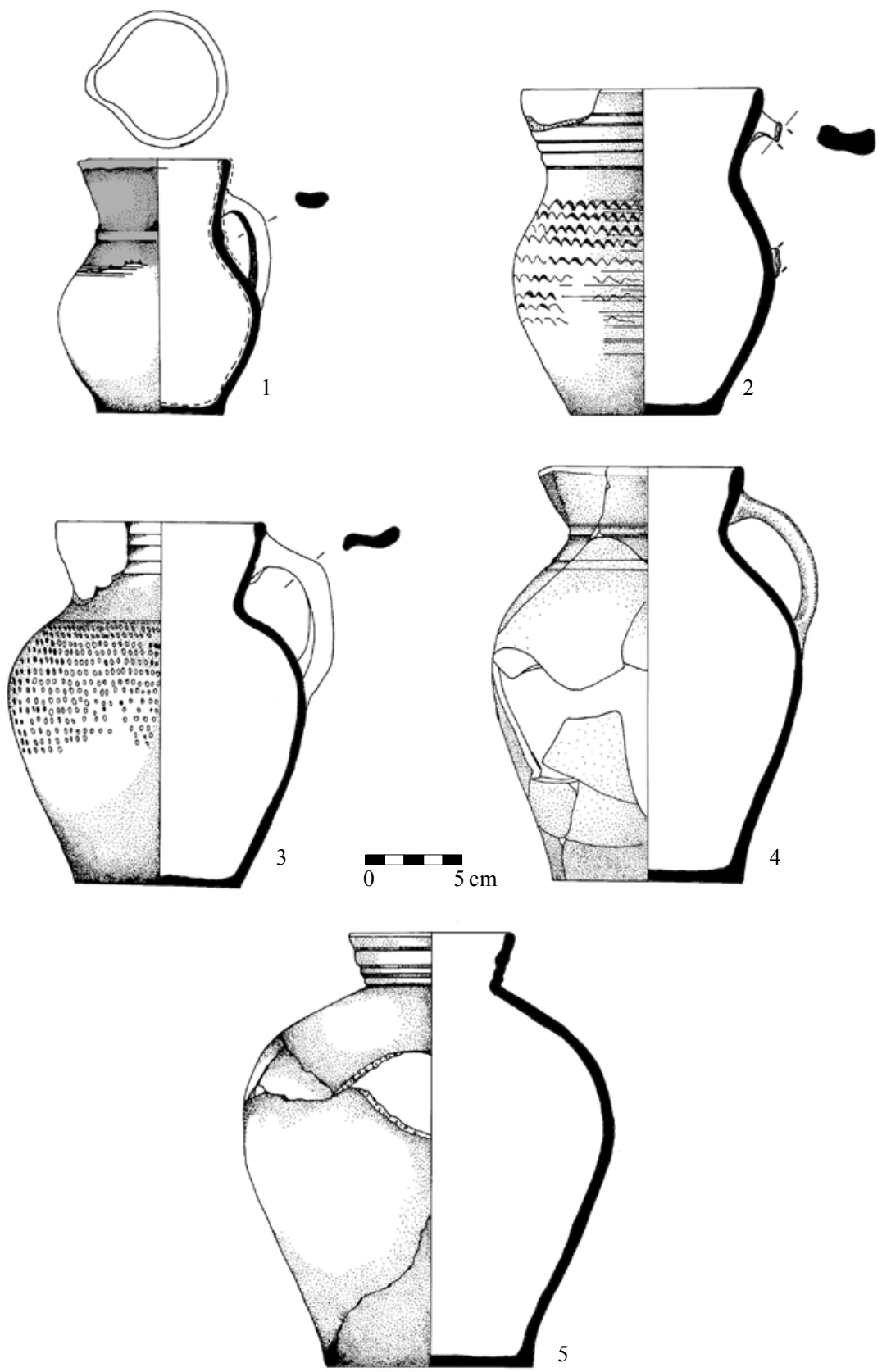

Obr. 10. Chrudim, Hradební ulice, jímka 938, řez C2J. Třetí fáze, výběr džbánů. 1 - inv. č. A31716, k. D2/141; 2 - inv. č. A31713, k. D2/141; 3 - inv. č. A31712, k. D2/141; 4 - inv. č. A31701, k. D2/141; 5 - inv. č. A31777, k. D2/145. Kresba B. Hlaváčová a P. Dudková.

Abb. 10. Chrudim, Hradební-Str., Grube 938, Schnitt C2J. Dritte Phase, Auswahl Krüge. 1 - Inv.-Nr. A31716, Kontext D2/141; 2 - Inv.-Nr. A31713, Kontext D2/141; 3 - Inv.-Nr. A31712, Kontext D2/141; 4 - Inv.-Nr. A31701, Kontext D2/141; 5 Inv.-Nr. A31777, Kontext D2/145. Zeichnung B. Hlaváčová und P. Dudková. 

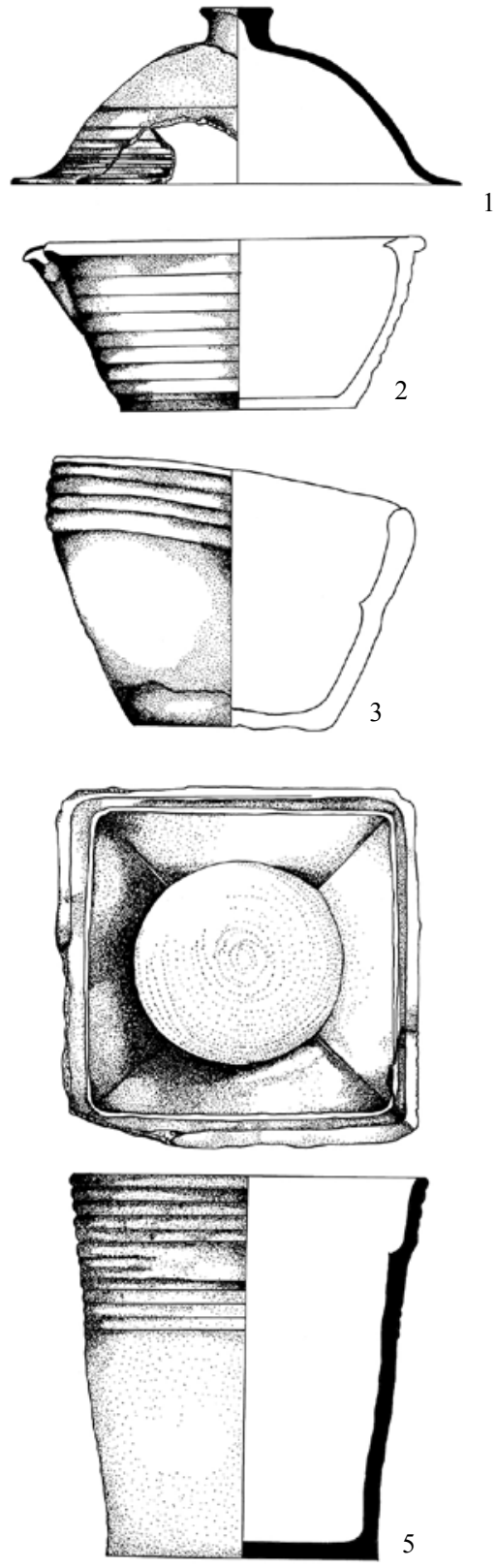
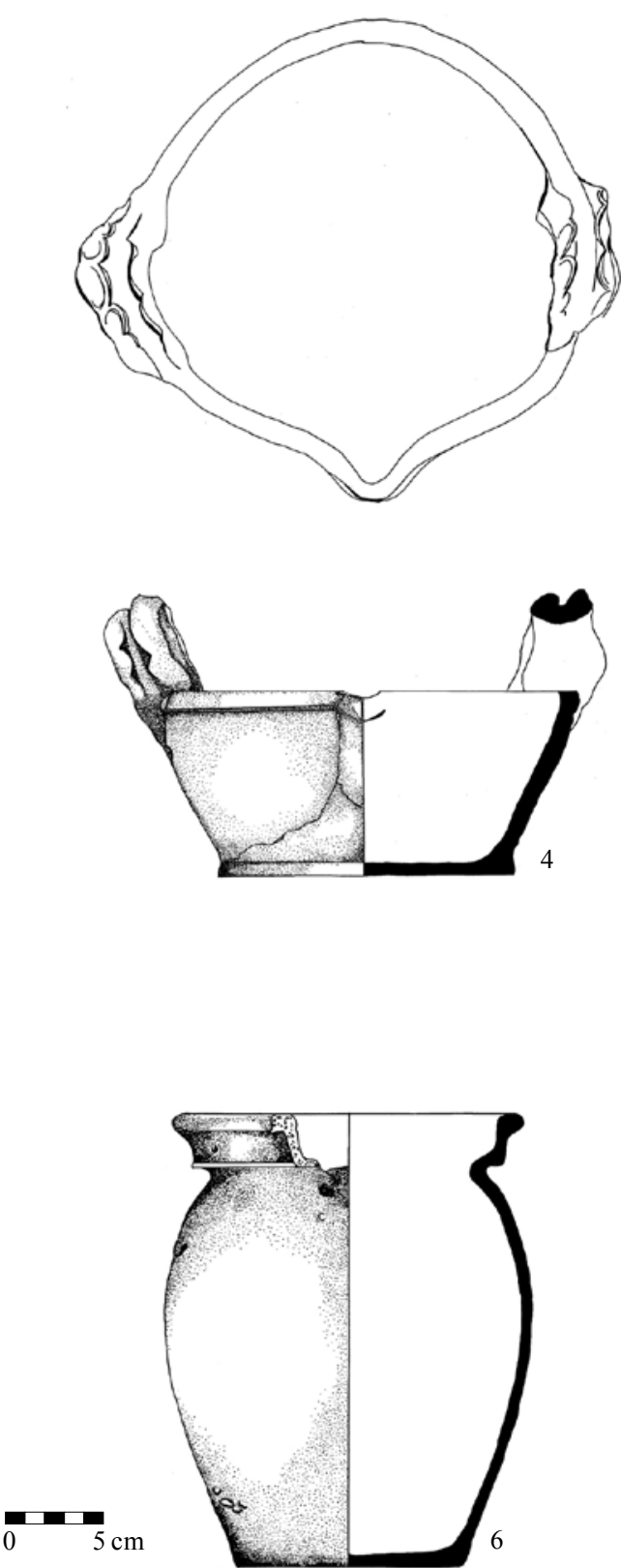

Obr. 11. Chrudim, Hradební ulice, jímka 938, řez C2J. Třetí fáze, keramika. 1 - poklička, inv. č. A31734, k. D2/142; 2 - mísa, inv. č. A31787, k. D2/142; 3 - kachel s pravoúhlým ústím, inv. č. A31796, k. D2/145; 4 - mísa, inv. č. A31794, k. D2/142. Zelený horizont. 5 - nádobkový kachel s pravoúhlým ústím, inv. č. A32341, k. D2/159; 6 - zásobnicová nádoba, severomoravský výrobní okruh, inv. č. A32339, k. D2/159. Kresba B. Hlaváčová a P. Dudková.

Abb. 11. Chrudim, Hradební-Str., Grube 938, Schnitt C2J. Dritte Phase, Keramik. 1 - Deckel, Inv.-Nr. A31734, Kontext D2/142; 2 - Schüssel, Inv.-Nr. A31787, Kontext D2/142; 3 - Kachel mit Rechteckmündung, Inv.-Nr. A31796, Kontext D2/145; 4 - Schüssel, Inv.-Nr. A31794, Kontext D2/142. Grüner Horizont. 5 - Topfkachel mit Rechteckmündung, Inv.-Nr. A32341, Kontext D2/159; 6 - Vorratsgefäß, nordmährischer Produktionsumkreis, Inv.-Nr. A32339, Kontext D2/159. Zeichnung B. Hlaváčová und P. Dudková. 

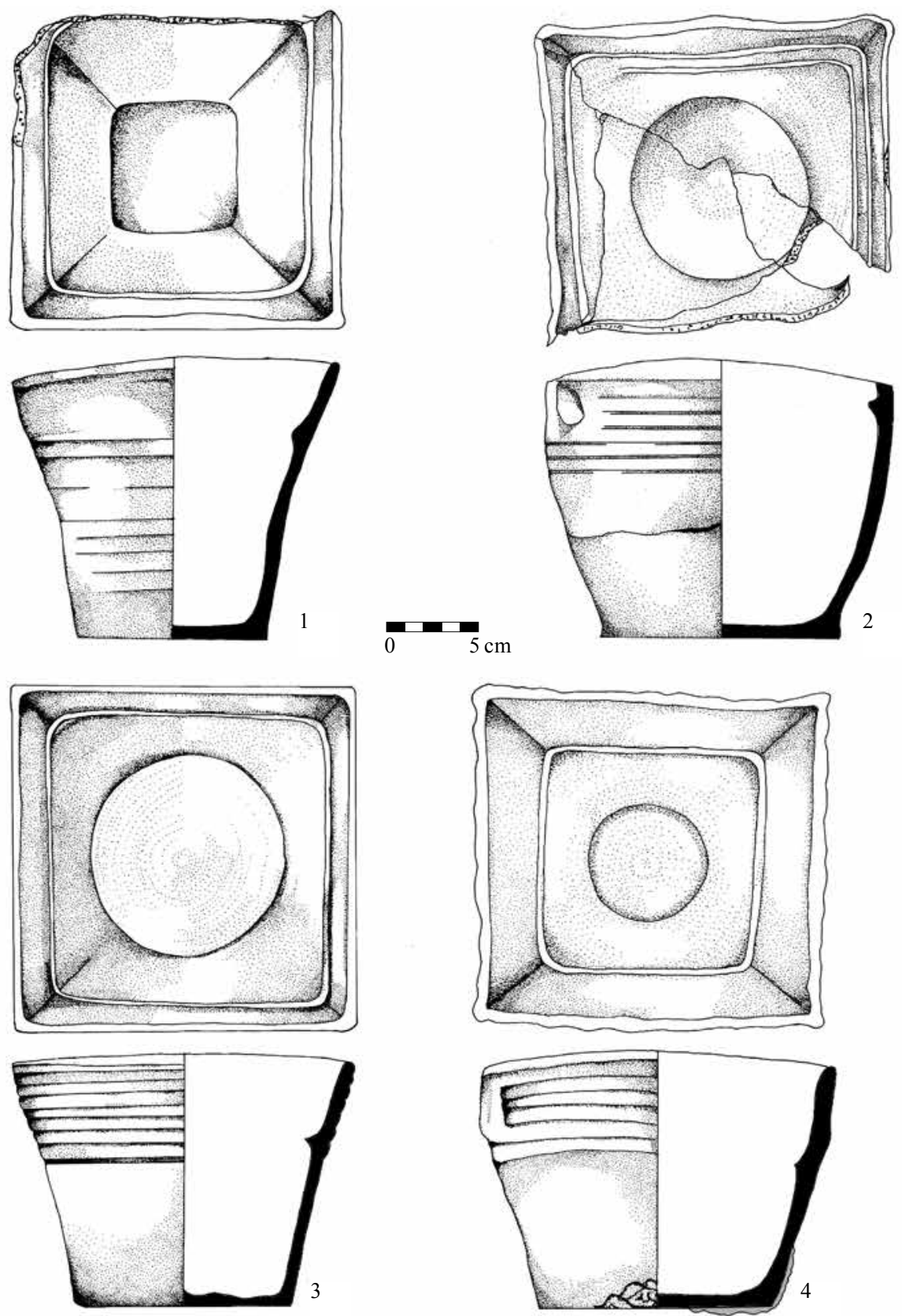

Obr. 12. Chrudim, Hradební ulice, jímka 938, řez C2J. Třetí fáze, nádobkové kachle s pravoúhlým ústím. 1 - inv. č. A31680, k. D2/141; 2 - inv. č. A31795, k. D2/145; 3 - inv. č. A31717, k. D2/141; 4 - inv. č. A31783, k. D2/145. Kresba B. Hlaváčová a P. Dudková.

Abb. 12. Chrudim, Hradební-Str., Grube 938, Schnitt C2J. Dritte Phase, Topfkacheln mit Rechteckmündung. 1 - Inv.-Nr. A31680, Kontext D2/141; 2 - Inv.-Nr. A31795, Kontext D2/145; 3 - Inv.-Nr. A31717, Kontext D2/141; 4 - Inv.-Nr. A31783, Kontext D2/145. Zeichnung B. Hlaváčová und P. Dudková. 

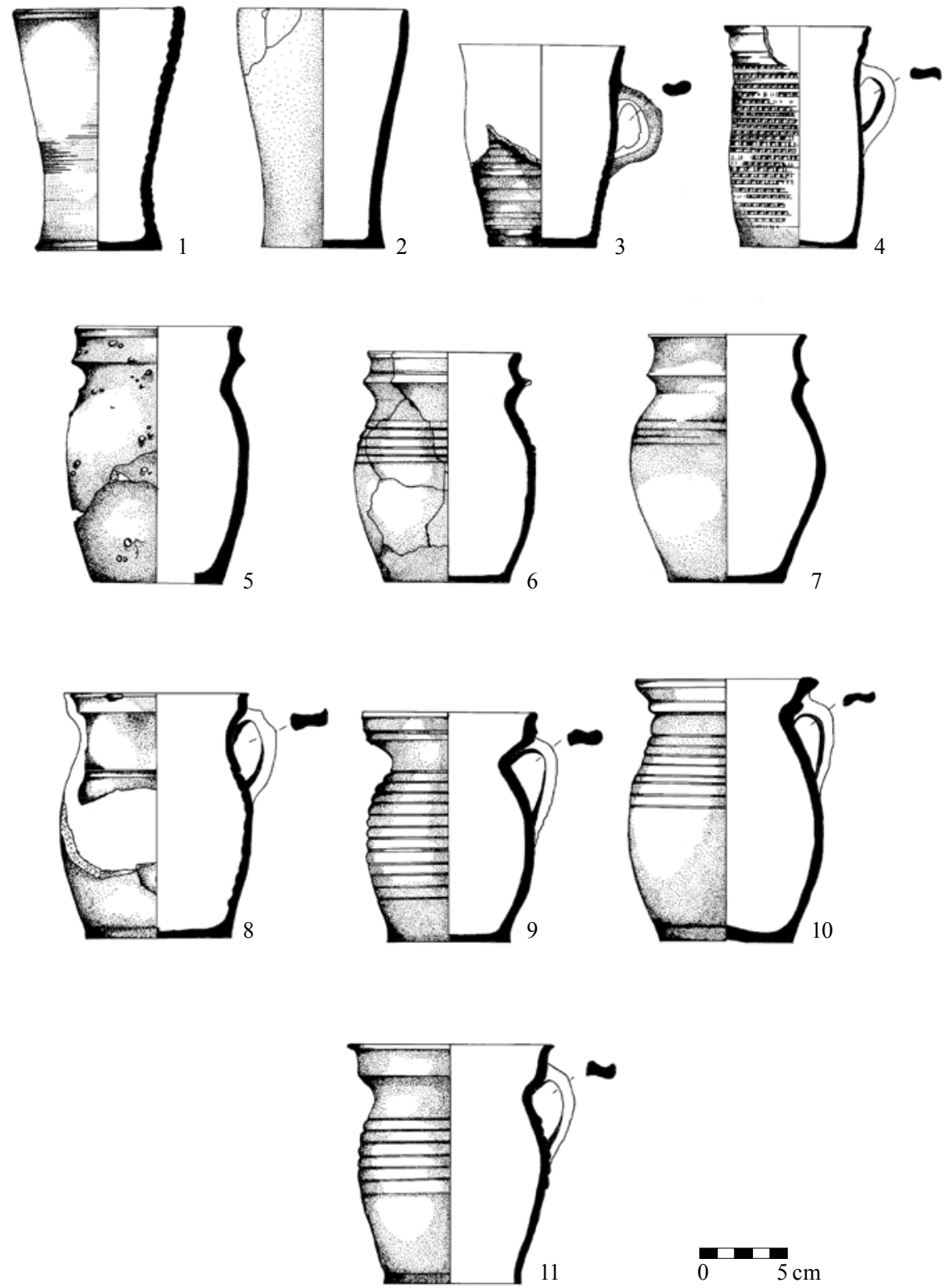

Obr. 13. Chrudim, Hradební ulice, jímka 938, řez C2J. Čtvrtá fáze, poháry. 1-2 - bezuché kónické poháry, inv. č. A32269, k. D2/158; 3-4 - redukční kónické poháry s uchem, inv. č. A31993, k. D2/148 a inv. č. A32084, k. D2/154; 5 - loštický pohár, inv. č. A32255, k. D2/157; 6-7 - poháry imitující loštické poháry, severomoravský výrobní okruh, inv. č. A31949 a A32261, k. D2/152 a D2/157; 8 a 11 - tzv. chrudimské poháry, inv. č. A31846 a A31882, k. D2/147 a D2/149 a inv. č. A31881, k. D2/149; 9-10 - prototypy tzv. chrudimských pohárů, inv. č. A31889, k. D2/149 a inv. č. A31855, k. D2/147. Kresba B. Hlaváčová a P. Dudková.

Abb. 13. Chrudim, Hradební-Str., Grube 938, Schnitt C2J. Vierte Phase, Becher. 1-2 - konische henkellose Becher, Inv.-Nr. A32269, Kontext D2/158; 3-4 - konische Henkelbecher, Reduktionskeramik, Inv.-Nr. A31993, Kontext D2/148 und Inv.-Nr. A32084, Kontext D2/154; 5 - Loschtitzer Becher, Inv.-Nr. A32255, Kontext D2/157; 6-7 - Loschtitzer Becher imitierende Becher, nordmährischer Produktionsumkreis, Inv.-Nr. A31949 und A32261, Kontext D2/152 und D2/157; 8 und 11 - sog. Chrudimer Becher, Inv.-Nr. A31846 und A31882, Kontext D2/147 und D2/149 und Inv.-Nr. A31881, Kontext D2/149; 9-10 Prototypen sog. Chrudimer Becher, Inv.-Nr. A31889, Kontext D2/149 und Inv.-Nr. A31855, Kontext D2/147. Zeichnung B. Hlaváčová und P. Dudková. 

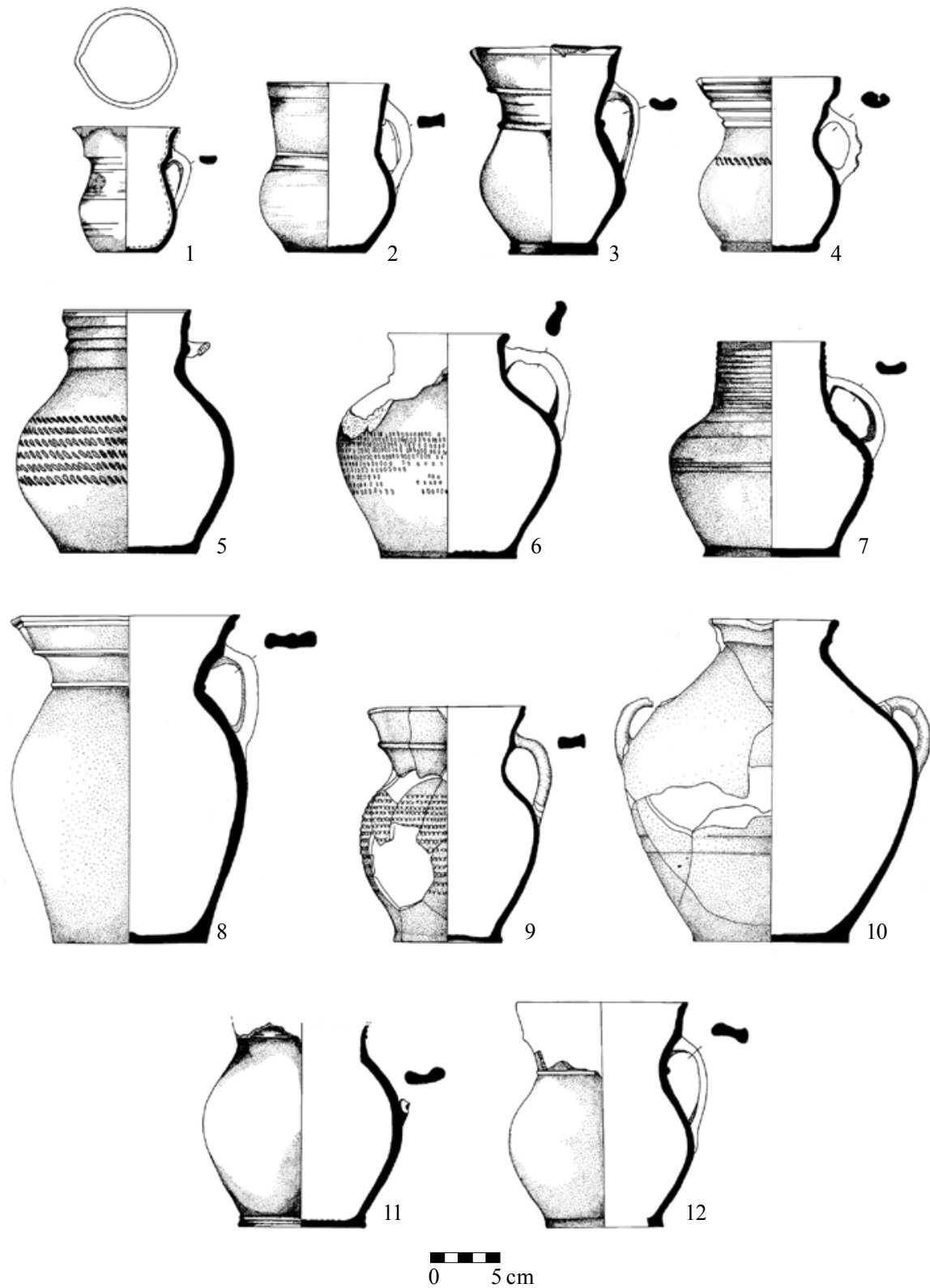

Obr. 14. Chrudim, Hradební ulice, jímka 938, řez C2J. Čtvrtá fáze, džbány. 1 - inv. č. A32336, k. D2/159; 2 - inv. č. A31936, k. D2/151; 3 - inv. č. A32344, k. D2/159; 4 - inv. č. A31962, k. D2/152; 5 - inv. č. A31337, k. D2/159; 6 - inv. č. A31960, k. D2/148; 7 - inv. č. A32164, k. D2/158; 8 - inv. č. A32264, k. D2/158; 9 - inv. č. A32285 a A32347, k. D2/159; 10 - inv. č. A32285, A32283 a A33848, k. D2/159; 11 - inv. č. A32242, k. D2/157; 12 - inv. č. A32271, k. D2/158. Kresba B. Hlaváčová, P. Dudková a K. Holínková.

Abb. 14. Chrudim, Hradební-Str., Grube 938, Schnitt C2J. Vierte Phase, Krüge. 1 - Inv.-Nr. A32336, Kontext D2/159; 2 Inv.-Nr. A31936, Kontext D2/151; 3 - Inv.-Nr. A32344, Kontext D2/159; 4 - Inv.-Nr. A31962, Kontext D2/152; 5 - Inv.-Nr. A31337, Kontext D2/159; 6 - Inv.-Nr. A31960, Kontext D2/148; 7 - Inv.-Nr. A32164, Kontext D2/158; 8 - Inv.-Nr. A32264, Kontext D2/158; 9 - Inv.-Nr. A32285 und A32347, Kontext D2/159; 10 - Inv.-Nr. A32285, A32283 und A33848, Kontext D2/159; 11 - Inv.-Nr. A32242, Kontext D2/157; 12 - Inv.-Nr. A32271, Kontext D2/158. Zeichnung B. Hlaváčová, P. Dudková und K. Holínková. 

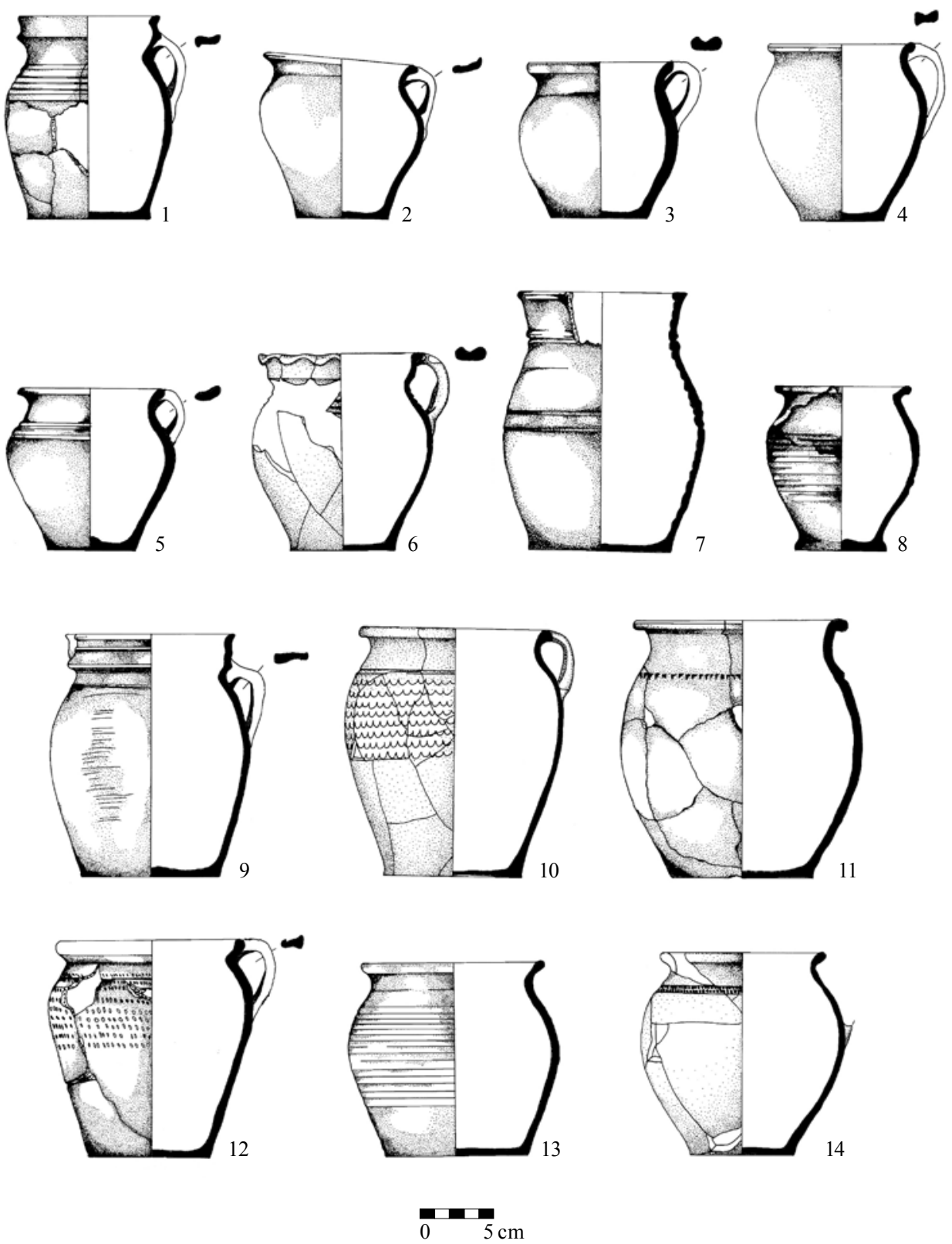

Obr. 15. Chrudim, Hradební ulice, jímka 938, řez C2J. Čtvrtá fáze, hrnce. 1 - inv. č. A32142, k. D2/156; 2 - inv. č. A32084, k. D2/156; 3 - inv. č. A32334, k. D2/159; 4 - inv. č. A31601, k. D2/157; 5 - inv. č. A32343, k. D2/159; 6 - inv. č. A32285 a A32347, k. D2/159; 7 - inv. č. A32262, k. D2/157; 8 - inv. č. A31857, k. D2/147; 9 - inv. č. A32268, k. D2/158; 10 - inv. č. A31901, k. D2/149; 11 - inv. č. A32057, k. D2/148; 12 - inv. č. A31861, k. D2/146; 13 - inv. č. A32259, k. D2/157; 14 - inv. č. A33198, k. D2/148. Kresba B. Hlaváčová, P. Dudková a K. Holinková.

Abb. 15. Chrudim, Hradební-Str., Grube 938, Schnitt C2J. Vierte Phase, Töpfe. 1 - Inv.-Nr. A32142, Kontext D2/156; 2 Inv.-Nr. A32084, Kontext D2/156; 3 - Inv.-Nr. A32334, Kontext D2/159; 4 - Inv.-Nr. A31601, Kontext D2/157; 5 - Inv.-Nr. A32343, Kontext D2/159; 6 - Inv.-Nr. A32285 und A32347, Kontext D2/159; 7 - Inv.-Nr. A32262, Kontext D2/157; 8 - Inv.-Nr. A31857, Kontext D2/147; 9 - Inv.-Nr. A32268, Kontext D2/158; 10 - Inv.-Nr. A31901, Kontext D2/149; 11 - Inv.-Nr. A32057, Kontext D2/148; 12 - Inv.-Nr. A31861, Kontext D2/146; 13 - Inv.-Nr. A32259, Kontext D2/157; 14 - Inv.-Nr. A33198, Kontext D2/148. Zeichnung B. Hlaváčová, P. Dudková und K. Holinková. 
které se mohou objevit i ve svrchnějších partiích 4. horizontu (k tomuto jevu Orna et al. 2011, $67-75)$.

Nárůst počtu pohárových nádob a džbánů (zde shledáváme četné analogie v čáslavské produkci - zejména džbány s kónickým hrdlem a baňatým mírně stlačeným tělem - obr. 14:5-7 Čermák 1897, 10; 1897a, 213-224; Čermák 1898; Florián 1914, 67-68; Frolík a kol. 1999, 44, č. kat. 215; Pavlů 1982; Tomášek 1995) lze do značné míry spojovat s obnovením trhů po roce 1435. Z keramické produkce se zcela vymyká dvouuchý džbán (obr. 14:10), k němuž se nepodařilo nalézt analogie. Náplň tohoto horizontu doplňuje archaicky vyhlížející kachel s pravoúhlým ústím (obr. 11:5) a zlomky baňkových kachlů.

\subsection{Sklo}

Zajímavé výsledky přinesl rozbor skla. Jímka 938 byla nálezově druhou nejbohatší jímkou na lokalitě, obsahovala více než 1300 fragmentů skla. Na prvním místě byla jímka 943 na sousední parcele (Kozáková-Frolík 2011; Kozáková-Klikarová-Frolík 2010), kde byly nalezeny i velmi ojedinělé kusy v nejstarších vrstvách (např. číše s choboty nebo importy). Početný soubor bylo možné rozdělit do tř́i základních chronologických etap (obr. 3), které se mírně odchylují od datování keramických nálezů. Spodní část výplně, v rozmezí uloženin D2/159 až D2/137 (níže položené vrstvy sklo neobsahovaly), obsahovala sklo gotické (4. fáze). Následoval úzký předěl (uloženiny D2/135 a D2/128) bez skleněných nálezů a uloženina D2/129 s pozdně gotickou číškou/pohárem (3. fáze přechodná). Nad tímto předělem se nacházely uloženiny v rozmezí D2/123 až C2/124 = D2/114, které obsahovaly sklo renesančního tvarosloví (2. fáze). Zvlášt' je nutné zmínit uloženinu D2/118, která sama o sobě poskytla nejbohatší soubor skel z celé jímky (obr. 3 - 2. fáze bohatá). Nálezově odlišná byla také horní část výplně nad uloženinou C2/123. Tato horní část výplně jímky (rozmezí uloženin C2/111 = D2/108 až C2/104 = D2/104) poskytla barokní křídové nebo mladší sklo (1. fáze).

Gotická skla (4. fáze) ve spodní části výplně (uloženiny D2/137, D2/141, D2/145, D2/148, D2/149, D2/151, D2/152, D2/156, D2/157 a D2/159) se dochovala velmi torzovitě, což zkomplikovalo typologické určení nádob. Nejvíce zlomků je zdobeno perličkovitými nálepy (obr. 17:12-13) typickými pro číše českého typu (obr. 17:14 - Černá 2005). V nejspodnějších vrstvách (rozmezí D2/155 až D2/159) bylo identifikováno nejméně sedm nádob, a to číše českého typu, láhev a prstýnek (obr. 17:15). V uloženině D2/141 byly nalezeny fragmenty kulovité láhve s úzkým kónickým hrdlem (obr. 18:4), v D2/142 pak drobná tenkostěnná lahvička. Toto nejstarší sklo lze datovat do druhé poloviny 14. století, eventuálně do století patnáctého (Frýda 1990).

Mezi jediné dva zástupce pozdně gotického tvarosloví, které lze datovat do první poloviny 16. století, patřila horní část číšky/poháru (obr. 18:7) z přechodové uloženiny D2/129 (obr. 3 3. fáze) a spodní část poháru s organicky tvarovaným prstencem (obr. 17:7) z jinak chronologicky mladší uloženiny D2/118. Uložení tohoto nálezu může souviset s vybráním jímky, naznačeným v úvodu textu. Renesanční sklo (obr. 3 - 2. fáze) ze střední části jímky (uloženiny D2/114 = C2/124 a D2/116 až D2/119) bylo možno datovat do druhé poloviny 16. až poloviny 17. století. Nejvíce skla bylo nalezeno v uloženině D2/118 čítající téměř $90 \%$ renesančního skla této jímky. Byly zde identifikovány láhve, pohárky nejrůznějších tvarů, konvice, číšky, tzv. laboratorní sklo, pravděpodobně též džbánky, dále kuličky, prstýnek a okenní sklo ve formě terčíků a štípaných trojúhelníčků (obr. 16). Z fragmentů náležejících nejméně šesti různým láhvím byly rekonstruovány tři. Jedna silnostěnná čtyřboká s nízkým hrdlem, druhá tenkostěnná válcovitá s vypíchnutým dnem, obě hladké bez zdobení. Dle analogií je lze blíže datovat do poloviny 17. století (Hejdová 1981; Sedláčková-Rohanová a kol. 2016, 210-211). Třetí láhev je zdobena domácí obdobou benátské techniky filigránu se zatavením červených a bílých tyčinek (obr. 18:1). Tato láhev patří k luxusním výrobkům tehdejších skláren. Z provedených analýz bylo potvrzeno, že sklo použité pro výrobu této láhve včetně barevných tyčinek je draselného typu, který je charakteristický pro české sklárny (Kozáková 2009). Obdobně zdobené láhve jsou známé například z Opavy (Drahotová 2005, 167), Bratislavy, Brna a Veselí nad Moravou (Sedláčková-Rohanová a kol. 2016, 258). Výroba byla doložena na výrobní lokalitě Rejdice v první třetině 17. století (Hejdová 

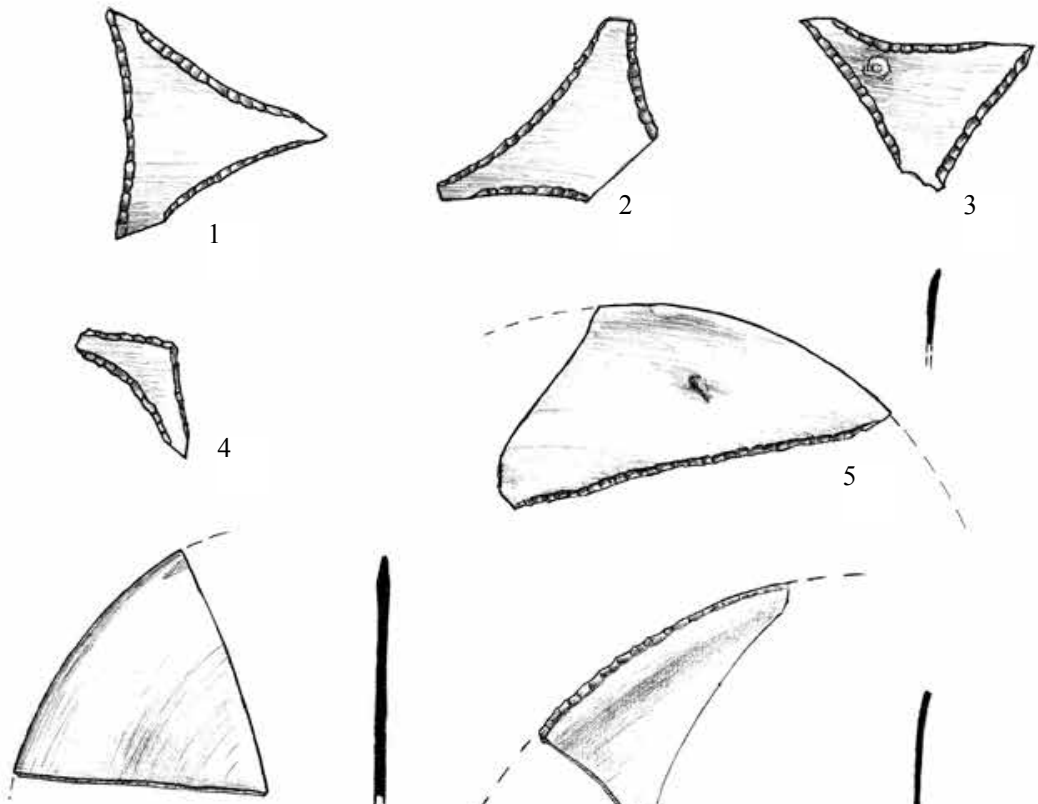

6
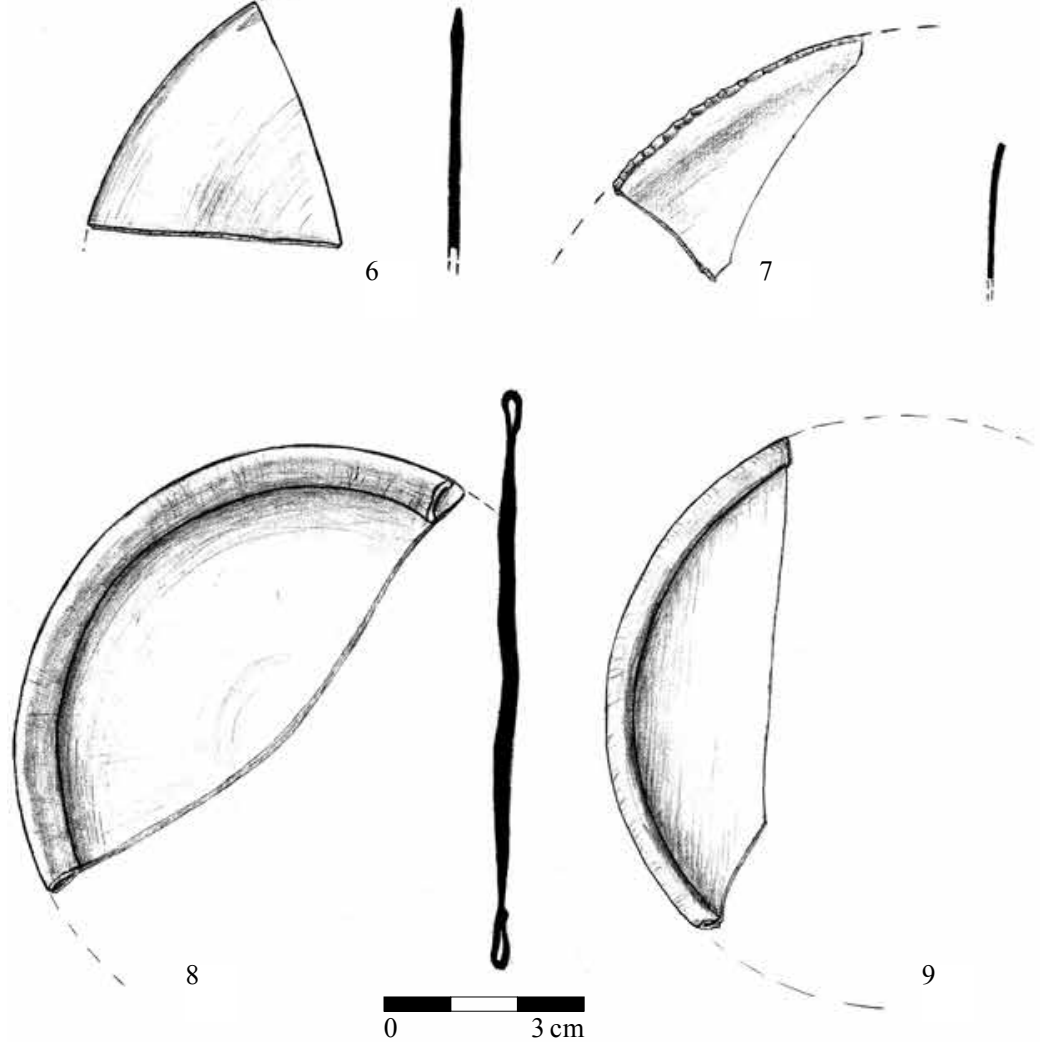

Obr. 16. Chrudim, Hradební ulice, jímka 938, řez C2J. Okenní sklo ve formě terčíků a štípaných trojúhelníčků. Kresba R. Kozáková.

Abb. 16. Chrudim, Hradební-Str., Grube 938, Schnitt C2J. Fensterglas in Form von runden Scheiben und abgepetzten Dreiecken. Zeichnung R. Kozáková.

1981), polotovary k výrobě filigránového skla byly též nalezeny v renesanční huti v Broumech (Žegklitz 2011, 207-208).

Nejvíce zastoupeným tvarem byl pohárek s vřetenovitou kupou a nožkou ze svinuté skleněné nitě (obr. 17:6). Kupa byla většinou zdobena optickým dekorem ve formě stáčených 

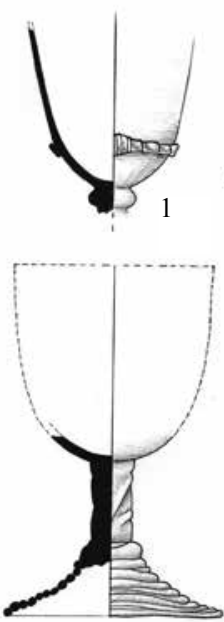

3
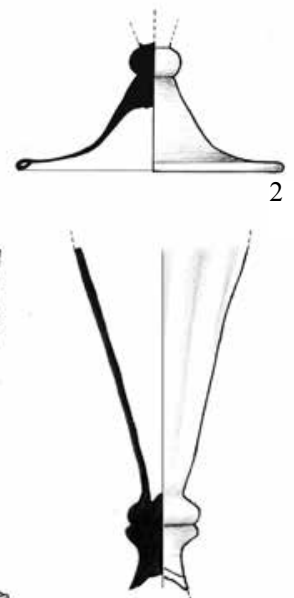

4
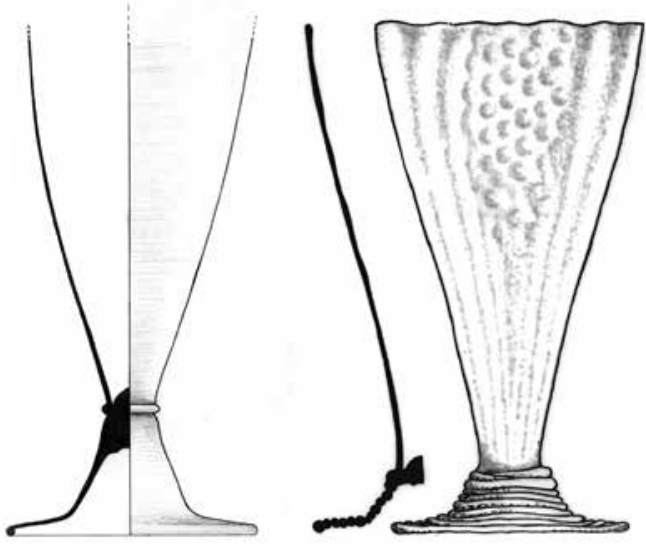

5

6

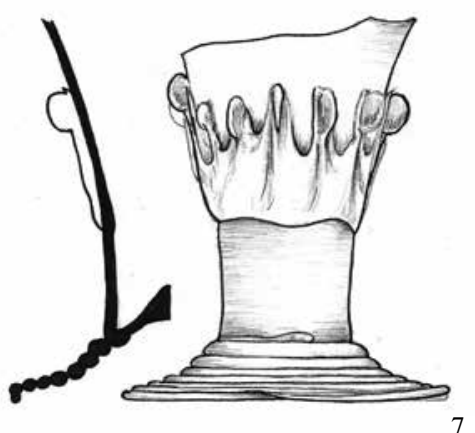

7
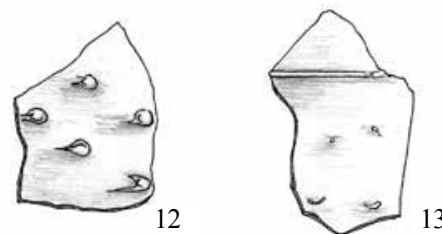

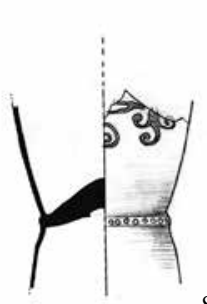

8


Obr. 17. Chrudim, Hradební ulice, jímka 938, řez C2J. 1 - pohárek s polovejčitou kupou, k. D2/118; 2 - hladká nožka pohárku, k. D2/118; 3 - nožka ze svinutého vlákna, k. D2/118; 4 - pohárek s vřetenovitou kupou a optickým dekorem, k. D2/119; 5 - pohár hladký, k. D2/118; 6 - pohár z picí série s dvojím optickým dekorem, k. D2/118; 7 - pohár s organicky tvarovaným prstencem, k. D2/118, inv. č. A31866; 8, 9 - malovaná číška, k. D2/118; 10, 11 - ryté sklo, inv. č. A32139, A30653; 12 - perličkové nálepy, k. D2/159; 13 - srpečkovité nálepy, k. D2/157; 14 - spodní část číše českého typu, k. D2/157; 15 - prstýnek, k. D2/157. Kresba R. Kozáková.

Abb. 17. Chrudim, Hradební-Str., Grube 938, Schnitt C2J. 1 - Trinkbecher mit halb-eiförmiger Kuppa, Kontext D2/118; 2 - glatter Fuß eines Trinkbechers, Kontext D2/118; 3 - Fuß aus gewickelter Glasfaser, Kontext D2/118; 4 - Trinkbecher mit spindelförmiger Kuppa und optischem Dekor, Kontext D2/119; 5 - glatter Trinkbecher, Kontext D2/118; 6 - Trinkbecher aus einer Serie mit doppeltem optischen Dekor, Kontext D2/118; 7 - Trinkbecher mit organisch geformten Kranz, Kontext D2/118, Inv.-Nr. A31866; 8, 9 - bemalter Becher, Kontext D2/118; 10, 11 - graviertes Glas, Inv.-Nr. A32139, A30653; 12 perlenförmige Aufschmelzungen, Kontext D2/159; 13 - sichelförmige Aufschmelzungen, Kontext D2/157; 14 - unterer Teil eines Bechers böhmischen Typs, Kontext D2/157; 15 - Ring, Kontext D2/157. Zeichnung R. Kozáková. 

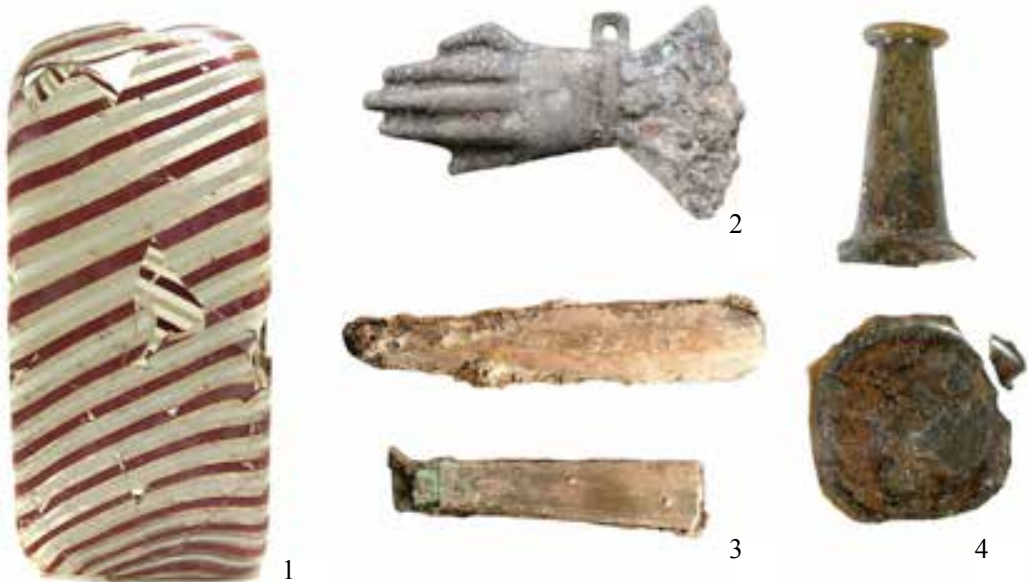

3
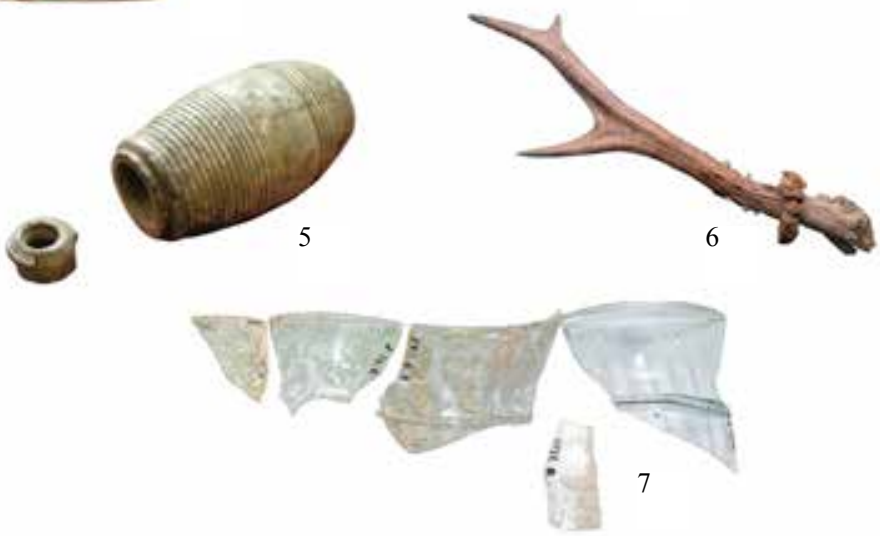

Obr. 18. Chrudim, Hradební ulice, jímka 938. 1 - láhev zdobená domácí obdobou benátské techniky filigránu se zatavením červených a bílých tyčinek, k. D2/118 + D2/119; 2 - votivní ruka z mosazného plechu, inv. č. A30771, k. D2/104; 3 - kostěné střenky. inv. č. A31260 a A31435, k. D2/118; 4 - kulovitá láhev s kónickým hrdlem, k. D2/142; 5 - kostěná dóza identifikovaná jako kuřácká pomůcka, inv. č. A31369, k. D2/118; 4 - srnčí paroh, pravděpodobně torzo lovecké trofeje, inv. č. A32257, k. D2/118; 7 - horní část číšky/pohárku, inv. č. A31573, k. D2/129. Rủzná měřítka. Foto R. Kozáková a J. Frolík.

Abb. 18. Chrudim, Hradební-Str., Grube 938. 1 - Flasche mit heimischer Analogie venezianischer Filigrantechnik und eingeschmolzenen roten und weißen Stäbchen, Kontext D2/118 + D2/119; 2 - Votivhand aus Messingblech, Inv.-Nr. A30771, Kontext D2/104; 3 - Griffe aus Bein. Inv.-Nr. A31260 und A31435, Kontext D2/118; 4 - bauchförmige Flasche mit konischem Hals, Kontext D2/142; 5 - Dose aus Bein, als Rauchutensilie identifiziert, Inv.-Nr. A31369, Kontext D2/118; 4 - Rehgeweih, wahrscheinlich Torso einer Jagdtrophäe, Inv.-Nr. A32257, Kontext D2/118; 7 - oberer Teil eines Bechers, Inv.-Nr. A31573, Kontext D2/129. Verschiedene Maßstäbe. Foto R. Kozáková und J. Frolík.

vertikálních pruhů nebo vedle sebe kladených bublin. Častá byla kombinace obou typů zdobení na jednom pohárku, objevovaly se však i tvary zcela hladké (obr. 17:4-6). Rekonstruováno bylo devět celých profilů a zlomky nejméně dalších dvaceti kusů, přičemž některé z nich mají identickou podobu a pravděpodobně tak původně tvořily picí soupravu. Naopak v menším zastoupení se našly pohárky s polovejčitou kupou, které jsou jinak pro české prostředí častější (obr. 17:1, $3,4)$. Nalezené tvary pohárků jsou v městském nálezovém prostředí velmi rozšířené. V literatuře se uvádí, že se již v této době jednalo o levnější, a tudíž dostupnější zboží (Drahotová 2005). Sklovina byla zabarvena do světle zelených tónů, zčásti též nažloutlých či namodralých. Malované sklo bylo zastoupeno pouze čtyřmi zlomky z jedné nádoby s florálním dekorem, pravděpodobně číše na zvonovité patce (obr. 17:8,9). 




Obr. 19. Chrudim, Hradební ulice, jímka 938, řez C2J. Výběr železných, bronzových a kamenných předmětů. 1-2, 5, 7 železo, inv. č. A30727, k. D2/108; 3 - bronz, inv. č. A30668, k. D2/108; 4 - bronz, inv. č. A30822, k. D2/114; 6 - bronz, inv. č. A30599, k. D2/110; 8 - bronz, inv. č. A30668, k. D2/108; 9 - kámen, inv. č. A32257, k. D2/157. Kresba J. Frolík. Abb. 19. Chrudim, Hradební-Str., Grube 938, Schnitt C2J. Auswahl an Gegenständen aus Eisen, Bronze und Stein. 1-2, 5, 7 - Eisen, Inv.-Nr. A30727, Kontext D2/108; 3 - Bronze, Inv.-Nr. A30668, Kontext D2/108; 4 - Bronze, Inv.-Nr. A30822, Kontext D2/114; 6 - Bronze, Inv.-Nr. A30599, Kontext D2/110; 8 - Bronze, Inv.-Nr. A30668, Kontext D2/108; 9 - Stein, Inv.-Nr. A32257, Kontext D2/157. Zeichnung J. Frolík.

Nejmladší horizont skla (obr. 3 - 1. fáze) z horní části jímky (uloženiny C2/104 = D2/104, $\mathrm{C} 2 / 111=\mathrm{D} 2 / 108, \mathrm{C} 2 / 112=\mathrm{D} 2 / 110)$ byl datován do 18 . století. Největší podíl tvořilo sklo čiré, dobře odbarvené a vyčeřené. Fragmenty nádob byly hladké nebo zdobené hranováním. Jednalo se o silnostěnné sklo, které pochází ze širších den nádob, pravděpodobně pivních džbánů, a také drobné hranované kalíšky. Zlomky mohou mít souvislost s hospodou doloženou písemnými prameny. Těl a horních částí nádob (okrajů) se našlo velmi málo, okraje byly zakončované brusičsky sámováním. Identifikována byla též mohutná, hutnicky zdobená ucha, úzké hrdlo láhve a část trubičky. Tři fragmenty byly zdobeny rytím kotoučky (obr. 17:10, 11). Analýza potvrdila, že se jedná o křídové sklo, vyráběné od druhé poloviny 17. století. V domácnosti měštanského domu se však běžně mohlo používat až v 18. století, kdy se stává cenově dostupné i pro sociálně slabší vrstvy obyvatelstva. Součástí tohoto souboru jsou i světle nazelenalé úlomky drobných, blíže 
neurčitelných dutých tvarů a plochého skla, které však mohou být starší příměsí. Zastoupeno bylo ojediněle i sklo tmavě zelených odstínů a sklo modré.

\subsection{Nekeramické předměty}

Nekeramické nálezy jsou zastoupeny z největší části zlomky železných předmětů (celkem 543 kusů), fragmenty bronzovými, předměty a zlomky kostěnými a kamennými. Zastoupena je též struska a fragmenty textilu. Detailněji se nebudeme zabývat stavebním materiálem (cihly, prejzy - Pavlišová 2015) a mazanicí (Netolický 2010).

Železné předměty nepodávají příliš jednoznačnou výpověd'. Především jejich velká část je funkčně neurčitelná, nejčastěji ve formě amorfních zlomků. Přidržíme-li se rozdělení a barevného označení horizontů jako u skla (obr. 3), lze konstatovat, že s rostoucím stáŕím uloženin přibývá neurčitelných předmětů. V horizontu barokního stáří (po třicetileté válce - 1 . fáze) bylo objeveno celkem 141 předmětů, z toho 24 neurčitelných (17\%). V horizontu renesančním (2. fáze) to bylo 331 předmětů, mezi nimi 94 neurčitelných (28\%). Ve spodním (gotickém - 3. a 4. fáze) horizontu bylo nalezeno pouze 71 předmětů, ovšem 60 funkčně neurčitelných (tj. $85 \%$ ). Příčinu spatřujeme ve větším rozrušení (korozi) starších zlomků. Pominuty jsou nálezy z povrchové uloženiny D2/104, v níž byl nalezen větší soubor (o váze několika kg) recentních želez. Nejmladší datovatelný předmět $\mathrm{v}$ této vrstvě představuje mosazná nábojnice $\mathrm{z}$ druhé poloviny 20 . století.

Většina určitelných nebo zčásti určitelných předmětů je chronologicky necitlivá. Mezi 365 předměty je 296 hřebíků ( 81 \%) a 57 zlomků plochých kování (16\%), tj. předmětů spojených se stavbou a jejím vybavením. Většina hřebíků je menších rozměrů a nepředpokládáme, že by se do jímky dostaly jako jednotlivosti, ale spíše jako součásti likvidovaných dřevěných předmětů, prričemž dřevo se nedochovalo. Ani zbylé předměty (12ks - 3\%) nejsou chronologicky citlivé a neposkytují nezávislé datování (jehla - D2/108; trojúhelníkový závěs dveří [?] - D2/108; tyčinka 4× - D2/108, C2/142, D2/141; hák/udidlo - D2/110; kulička - D2/118; nůž 3× - D2/118, z toho jednou část rukojeti s bronzovým kováním; objímka - D2/118). Podle rozdělení železných předmětů (Belcredi 1989) spadá převážná většina určitelných předmětů do kategorie stavebních kování (ukázky obr. 19:1, 5, 7), hřebů a součástí dveří (závěs? - obr. 19:2), eventuálně do kategorie osobní a domácí výbavy (nůž, sem řadíme i jehlu).

Objeveny byly také předměty z barevných kovů, převážně bronzu. Většinu z nich tvoří drobné amorfní zlomky nebo neurčitelná drt'. Ze zbylých můžeme identifikovat šatní háček (?) (D2/110 - obr. 19:6), knoflík (D2/108 - obr. 19:3), přezku (?) (D2/114 - obr. 19:4) a zlomek jehlice (D2/108 - obr. 19:8). Všechny pocházejí z části výplně uložené po třicetileté válce. Z období předchozího je to zlomek ploché tyčinky (D2/118), nezdobený bronzový kroužek (D2/118) a zlomek blíže neurčitelného plochého kování (D2/123). Mezi předměty z barevných kovů byla nalezena také ručička lisovaná z mosazného plechu (D2/104), nejspíše votivního účelu. Chronologicky se jedná o starší předmět druhotně přemístěný do velmi mladé situace (obr. 18:2).

Výčet kovových předmětů uzavřeme čtyřmi mincemi, $\mathrm{z}$ toho třemi v renesančním horizontu (D2/118) a jednou v horizontu gotickém (D2/141). Podle velikosti se jednalo o drobné mince. Všechny jsou však natolik zkorodované, že je nelze identifikovat.

Zastoupeny jsou také kostěné předměty. Ke stolnímu vybavení patří části - střenky - nožů (obě z uloženiny z D2/118 - obr. 18:3). Z téže uloženiny pochází také nevelká kostěná dóza se šroubovacím závěrem, identifikovaná jako součást kuřáckého vybavení (Brongers 1964 - obr. 18:5). Mezi kostěné artefakty řadíme také neopracovaný srnčí paroh (D2/118). Z parcely a ani z celé zkoumané plochy nejsou doklady opracování kostí nebo parohů, proto uvažujeme o lovecké trofeji (obr. 18:6).

Výčet uzavřeme kamennými artefakty. Tvoří je kamenný brousek (uloženina D2/157 - obr. 19:9), který náleží do gotického horizontu, a křesací kameny, eventuálně jejich zlomky (5 ks z uloženiny D2/108, 2 ks z uloženiny D2/114). Všechny pocházejí z horizontu datovaného do období po třicetileté válce (obr. 20). 

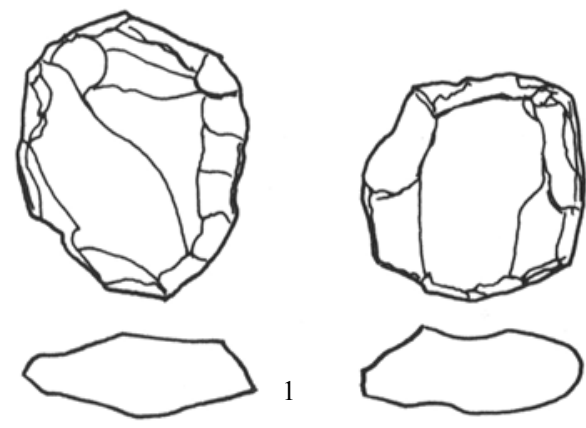

1
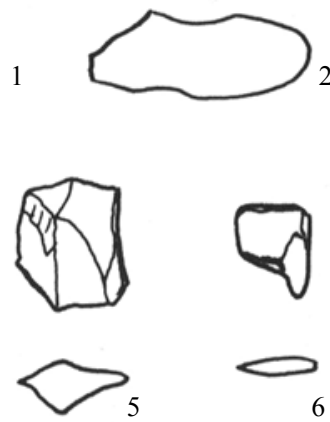
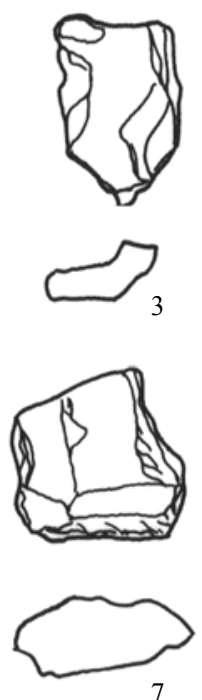

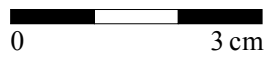

Obr. 20. Chrudim, Hradební ulice, jímka 938, řez C2J. Pazourkové křesací kameny - tzv. flinty. 1-2 - inv. č. A30668, k. D2/108; 3 - A 30751, k. D2/108; 4 a 7 - inv. č. A30784, k. D2/114; 5-6 - inv. č. 30728, k. D2/108. Kresba J. Frolík.

Abb. 20. Chrudim, Hradební-Str., Grube 938, Schnitt C2J. faustkeilartige Feuersteine - sog. Flinte. 1-2 - Inv.-Nr. A30668, Kontext D2/108; 3 - A 30751, Kontext D2/108; 4 und 7 - Inv.-Nr. A30784, Kontext D2/114; 5-6 - Inv.-Nr. 30728, Kontext D2/108. Zeichnung J. Frolík.

\section{Závěr}

Chronologický rozdíl mezi jednotlivými částmi výplně a poměrně jednoznačně identifikovatelné předěly ve stratigrafii ukazují, že jímka fungovala dlouhodobě a pravděpodobně nikoliv jako jediná na parcele. Zřízena byla podle nálezů z nejstaršího horizontu ve druhé polovině 14. století. Chronologické (tř̌i až čtyři časová období) a stratigrafické předěly, které jsou mírně odlišné, ale nikoliv proti sobě stojící v př́ípadě skla a keramiky (obr. 3), dokládají, že jímka byla opakovaně vyprazdňována, a to nejméně dvakrát až třikrát. Dalším procesem bylo sesedání obsahu, které vyvolávalo nutnost vyplňovat vzniklou depresi. V př́ípadě jímky 938 jsme ji schopni identifikovat po vyřazení jímky z provozu (od úrovně vrstvy D2/123 výše).

Archeologický materiál ukazuje, že jímka ukončila svou funkci nejspíše v souvislosti $\mathrm{s}$ událostmi třicetileté války, kdy navíc většina staveb v domovním bloku zanikla nebo byla natolik poškozena, že nebyla obyvatelná.

Nálezy ukazují na luxusněji vybavenou domácnost, jak dokládají pro starší horizonty především nálezy skla, převyšující počtem množství doložené z jiných zkoumaných chrudimských jímek. Mezi luxusnější zboží řadíme také loštické poháry. Popisovaná jímka 938 obsahuje stejné množství této komodity, jaké poskytly všechny jímky na čtyřech zkoumaných parcelách ve Filištínské ulici čp. 37/I až 40/I (Frolík-Sigl 1998, 118-119; k výskytu loštických pohárů ve východních Čechách Bláha-Frolík-Sigl 2003). Pro mladší horizonty jsou to kromě bohatě zastoupeného skla kuřácké pomůcky a také nález srnčího parohu, identifikovaný jako lovecká trofej. Podobný obraz nabízejí také další, dosud nepublikované, jímky na stejné parcele (např. 


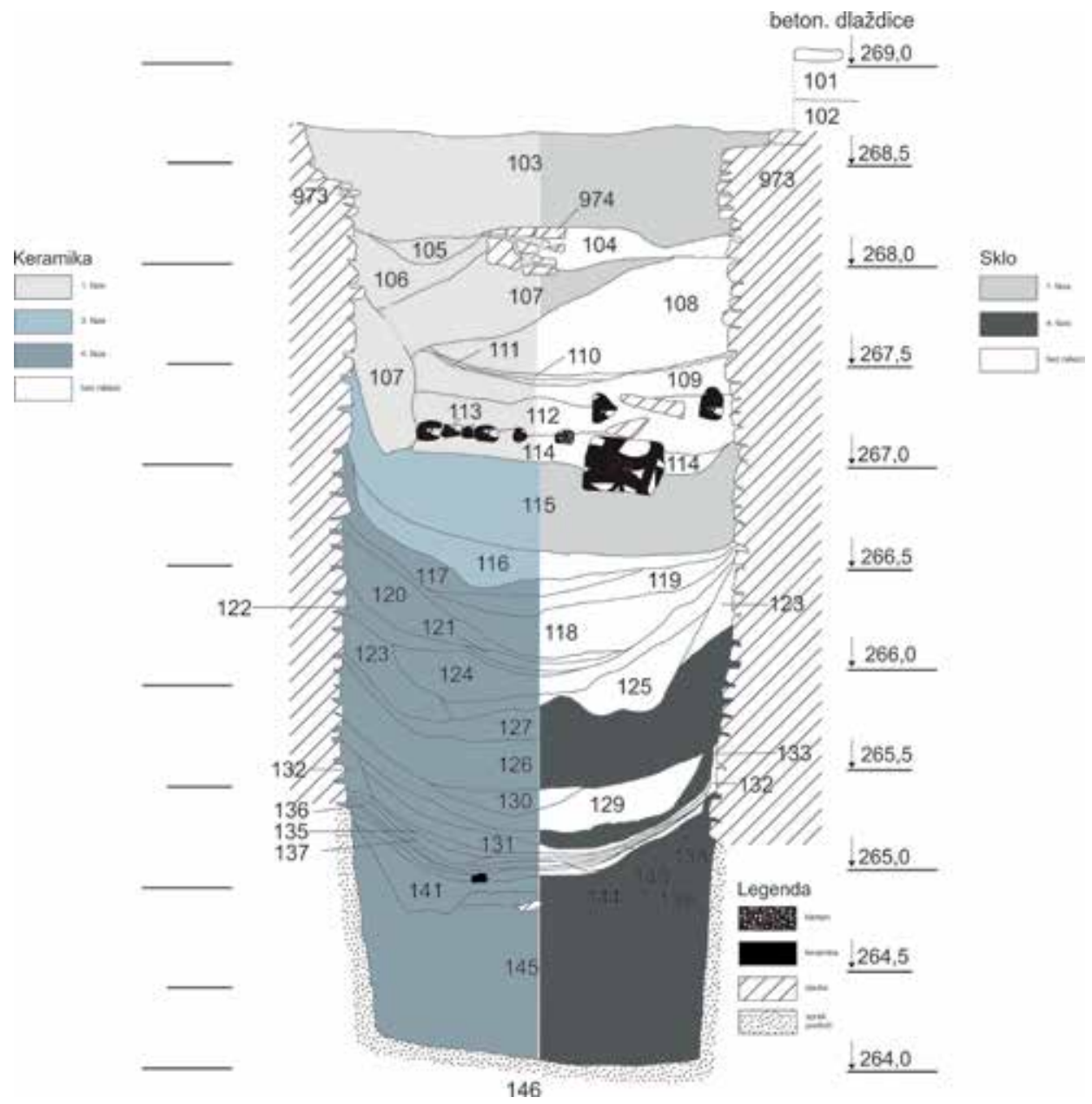

Obr. 21. Chrudim, Hradební ulice. Jímka 973 s vyznačením horizontů podle nálezů keramiky a skla. Vlevo horizonty podle nálezů keramiky. 1. fáze - 17.-18. století, 3. fáze - 2. polovina 15. a 16. století, 4. fáze - konec 14. a 1. polovina 15. století. Vpravo horizonty podle nálezů skla. 1. fáze - 17.-18. století, 4. fáze-14.-15. století. Vyhotovil J. Musil.

Abb. 21. Chrudim, Hradební-Str.. Grube 973 mit gemäß den Keramik- und Glasfunden eingezeichneten Horizonten. Links Horizonte gemäß den Keramikfunden. 1. Phase - 17.-18. Jahrhundert, 3. Phase - 2. Hälfte 15. und 16. Jahrhundert, 4. Phase - Ende 14. und 1. Hälfte 15. Jahrhundert. Rechts Horizonte gemäß den Glasfunden. 1. Phase - 17.-18. Jahrhundert, 4. Phase - 14.-15. Jahrhundert. Erstellt von J. Musil.

importované sklo v jímce 932). Nálezy nedovolují úvahy o řemesle majitele nemovitosti. I tyto strohé závěry jsou však v souladu s umístěním jímky (i parcely) ve čtvrti zvané Bohatá. Nabízí se srovnání s vyhodnocenými jímkami z Chrudimi - Filištínské ulice čp. 37/I-40/I (Frolík-Sigl 1998; Sehnoutková 2011).

Vrstva s největším množstvím luxusnějších nálezů (uloženina D2/118 - mince, součásti př́borů, paroh, fajánse, kamenina, mezzomajolika ad.) poskytla také velký soubor skla sestávající ze sérií stejných nádob. Ukazuje na jednorázové vyklízení, nejspíše po nějaké katastrofě. Podle chronologie těchto předmětů se tak stalo v souvislosti s událostmi třicetileté války (podobný jev jednorázového vyklizení byl identifikován v souvislosti se stejnou válkou také v jímkách na Pražském hradě - Blažková-Frolík-Žegklitzová 2012). 


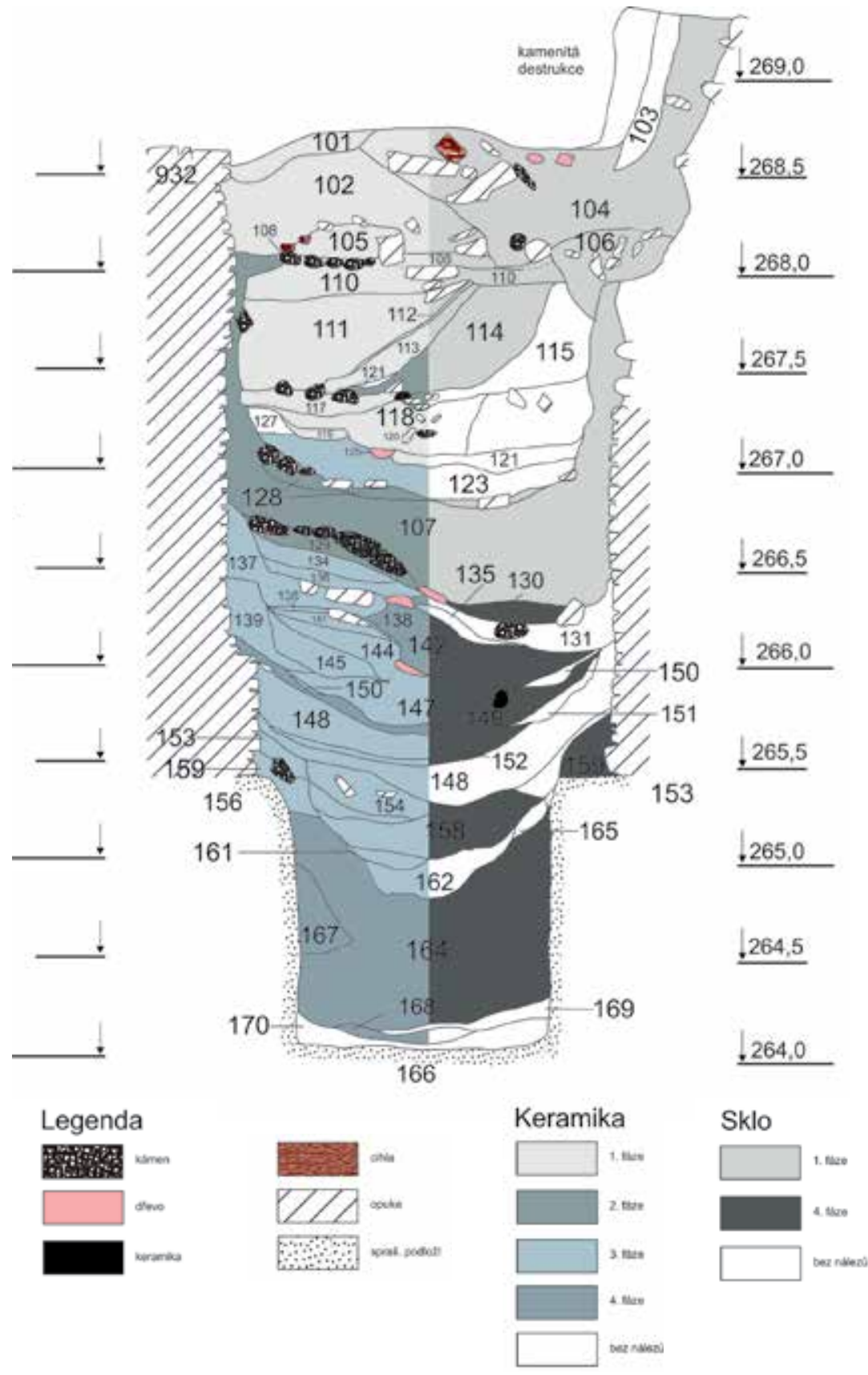

Obr. 22. Chrudim, Hradební ulice. Jímka 932 s vyznačením horizontů podle nálezů keramiky a skla. Vlevo horizonty podle nálezů keramiky. 1. fáze - 17.-18. století, 2. fáze - 2. polovina 15.-16. století, 3. fáze - 2. polovina 14. - 1. polovina 15. století, 4. fáze - 2. polovina 13.-1. polovina 14. století. Vpravo horizonty podle nálezů skla. 1. fáze - 17.-18. století, 4. fáze 14.-15. století. Vyhotovil J. Musil.

Abb. 22. Chrudim, Hradební-Str.. Grube 932 mit gemäß den Keramik- und Glasfunden eingezeichneten Horizonten. Links Horizonte gemäß den Keramikfunden. 1. Phase - 17.-18. Jahrhundert, 2. Phase - 2. Hälfte 15.-16. Jahrhundert, 3. Phase 2. Hälfte 14. - 1. Hälfte 15. Jahrhundert, 4. Phase - 2. Hälfte 13.-1. Hälfte 14. Jahrhundert. Rechts Horizonte gemäß den Glasfunden. 1. Phase - 17.-18. Jahrhundert, 4. Phase-14.-15. Jahrhundert. Erstellt von J. Musil. 
Ve výplni jímky 938 byl identifikován proces opakovaného zaplňování a částečného vybírání zásypu a doklady poměrně dlouhého fungování této jímky (14. až 17. století). Podobně je tomu také u dalších jímek, jejichž stratigrafie a nálezový obsah již byly vyhodnoceny. Př́íkladem může být jímka 973 se třemi jednoduše vymezitelnými horizonty (obr. 21) nebo jímka 932 (obr. 22). V tomto príípadě zřjejmě částečně identifikujeme i druhotně přemístěné vrstvy (soubory), např́íklad uloženina s nálezy 14. až 15. století na bázi navážek 17. až 18. století, nebo blok vrstev s keramikou 15. až 16. století v rámci těchto navážek.

Jímka 938 (a také další jímky z Chrudimi - Hradební ulice, jejichž publikace se připravuje) je př́́kladem jímky s velmi složitým stratigrafickým a dlouhodobým vývojem, s kterým se zatím setkáváme spíše ojediněle (Cymbalak-Matějková 2012). Publikované př́íklady nálezových souborů z odpadních jímek, eventuálně ze studní druhotně využitých jako jímky, se soustřed’ují spíše na časově sevřené celky (např. Bláha 1982; 1987; Klápště 2002; Krajíc a kol. 1998). Soubory s předměty z delšího časového období bývají považovány za problematické (Vencl 2001, 606-607, 610; reakce Klápště 2001). O možnosti nového využívání po opakovaném vybírání s ponecháním zbytků předchozího obsahu se uvažuje až v poslední době (Blažková a kol. 2016, 61-62), přičemž prokázání tohoto předpokladu je odvislé od způsobu výzkumu nebo (ne)dochování potřebné dokumentace (např. jímka C na Pražském hradě, Blažková-Vepřeková 2015, 503-587; Blažková a kol. 2016, 160). Pečlivá terénní práce a detailní dokumentace však dovolují rekonstrukci života na přilehlé parcele mnohem detailněji než soubory předmětů uložených v krátkém období.

\section{Literatura}

BAUER, I. a kol., 1986: Bauer, I.-Enders, W.-Kerkhoff-Hader, B.-Koch, R.-Stephan, G. H., Leitfaden zur Keramikbeschreibung. München.

BELCREDI, L., 1989: Terminologie, trrídění a kód středověkých kovových předmětů - Terminologie, Klassifizierung und Kode mittelalterlicher metallischer Gegenstände, AH 14, 437-472.

BLÁHA, J., 1982: Archeologický průzkum v Olomouci. Staveniště obchodního domu Prior, objekty XVII/73 a IV/73 (Keramika), sešit 1 - Archäologische Ausgrabungen in Olmütz, Baustelle des Warenhauses Prior, Befunde XVII/73 und IV/73 (Keramik). Heft 1. Olomouc.

- 1987: Archeologický průzkum v Olomouci. Staveniště obchodního domu Prior, objekty 5/78, 59/79 a 68/79 (Keramika), sešit 2 - Archäologische Ausgrabungen in Olmütz, Baustelle des Warenhauses Prior, Befunde 5/78, 59/79 und 68/79 (Keramik). Heft 2. Olomouc.

BLÁHA, R.-FROLÍK, J.-SIGL, J., 2003: Nálezy loštické keramiky ve východních Čechách. Př́ispěvek ke kontaktům východních Čech a severní Moravy - Funde der Lošticer Keramik in Ostböhmen. Beitrag zu den Kontakten Ostböhmens und Nordmährens, AH 28, 525-537.

BLAŽKOVÁ, G.-FROLÍK, J.-ŽEGKLITZOVÁ, J., 2012: Early Modern archaeological assemblages from Prague Castle and period written and iconopraphic sources - Raně novověké archeologické soubory z Pražského hradu a dobové písemné a ikonografické prameny - Frühneuzeitliche archäologische Fundkomplexe von der Prager Burg und zeitgenössische schriftliche und ikonographische Quellen, Studies in Post-Medieval Archaeology 4, 189-232.

BLAŽKOVÁ, G.-VEPŘEKOVÁ, J., 2015: Nálezy hmotné kultury z renesančních odpadních jímek Pražského hradu. Díl I. Katalog - Material Finds from the Renaissance Waste Pits at Prague Castle. Castrum Pragense 13. Praha.

BLAŽKOVÁ, G. a kol., 2016: Nálezy hmotné kultury z renesančních odpadních jímek Pražského hradu. Díl II. Studie - Material Finds from the Renaissance Waste Pits at Prague Castle. Castrum Pragense 13. Praha.

BLAŽKOVÁ-DUBSKÁ, G., 2007: House of the armoury scribe at Prague Castle, Studies in Post-Medieval Archaeology 2, 9-42.

BRONGERS, G. A., 1964: Pijpen en tabak. Amsterdam.

CYMBALAK, T.-MATĚJKOVÁ, K., 2012: Zpracování nálezů ze dvou odpadních jímek a úskalí jejich interpretace - Analysis from two cesspits and problems with their interpretaion, Staletá Praha XXVIII, $41-76$. 
ČERMÁK, K., 1897: Hrnčířská dílna v Čáslavi, Věstník českoslovanských museí a spolků archeologických II, 10.

- 1897a: Hrnčíři v Čáslavi a jejich památky, Památky archeologické a místopisné XVII, 212-224.

- 1898: Hrnčírny v Čáslavi ze XIV., XV. a XVI. věku, Zpráva musejního spolku „Včela Čáslavská“ za rok 1897-1898, 7-16.

ČERNÁ, E., 2005: Nálezy skel v sídlištním prostředí. In: Historie sklářské výroby v českých zemích, 84103. Praha.

DRAHOTOVÁ, O. a kol., 2005: Renesanční sklo v archeologických nálezech v Čechách a na Moravě. In: Historie sklářské výroby v českých zemích, 159-184. Praha.

DURDÍK, T., 1980: K chronologii keramiky 14. - počátku 15. století ve východní části středních Čech - Zur Chronologie der Keramik des 14. - bis Anfang des 15. Jahrhunderts im Ostteil Mittelböhmens, AH 5, 361-368.

- 1983: K výskytu bíle malované keramiky v Čechách (Sdělení k článku Z. Hazlbauera-J. Špačka) - Zum Vorkommen der weiss bemalten Keramik im Böhmen, AH 8, 211-213.

FLORIÁN, Č., s. d.: Topografie Chrudimi I. Rukopis. Státní Okresní archiv v Chrudimi. Fond Pozůstalost Vincence Floriána, kart. 1, inv. č. 16.

- 1914: Nález historické keramiky v Chrudimi, PA XXVI, 67-68.

FROLÍK, J., 2003: Kachle Chrudimska. Sbírky Regionálního muzea v Chrudimi. Chrudim.

FROLÍK, J.-HAZLBAUER, Z.-RÜCKEROVÁ, A., 1995: Chrudimský hrnčířský rod Medků a jeho kamnářské výrobky - Töpfergeslecht Medek von Chrudim und die Kachelzeugnisse, AH 20, 523-538.

FROLÍK, J.-MUSIL, J., 2007: Záchranné archeologické výzkumy v Chrudimi v roce 2006 - Archäologische Rettungsgrabungen im Chrudim im J. 2006. In: Archeologické výzkumy v Čechách 2006. Sborník referátů z informačního kolokvia. Zprávy České archeologické společnosti - Supplément 68 (Sklenár, K., ed.), 46-48. Praha.

- 2010: Záchranný archeologický výzkum v Hradební ulici v Chrudimi v roce 2006, Chrudimský vlastivědný sborník 14, 3-28.

- 2014: Nejstarší zástavba Chrudimi po založení města ve 2. polovině 13. století - Die älteste Bebauung in Chrudim nach der Stadtgründung in der 2. Hälfte des 13. Jahrhunderts, Forum urbes medii aevi VIII, $46-67$.

- 2016: Katalog archeologických nálezů z hradu Košumberka. 2. díl: kamnové kachle, část první. - Katalog der archäologischen Funde von der Burg Košumberk. 2. Teil: Die Ofenkacheln 1. Sbírky Regionálního muzea v Chrudimi 8/II. Praha - Chrudim.

FROLÍK, J.-SIGL, J., 1990: Soubor pozdně středověké keramiky z Chrudimi - Husovy ulice - A group of late mediaeval pottery from the town Chrudim (Husova street), Studies in Post-Medieval Archaeology 1, 269-284.

- 1998: Chrudim v pravěku a středověku. Obrazy každodenního života - Chrudim in Prehistory and the middle Ages. Pictures of everyday Life - Chrudim in der Urgeschchte und im Mittelalter. Bilder aus dem Alltagsleben. Chrudim.

FROLÍK, J. a kol., 1999: Frolík, J.-Hazlbauer, Z.-Charvát, P.-Šumberová, R.-Tomášek, M., Čáslav - místo pro život. Svědectví archeologie - Čáslav - die Städte für das Leben. Aussagen der Archäologie - Čáslav - A place for Living. The Testimony that Archeology gives. Čáslav.

FRÖHLICH, J., 2015: Archeologické nálezy mezzomajolik - Archeological finds of mezzomaiolica, ASČ $19,831-838$

FRÝDA, F., 1990: Typologie středověkého skla v Čechách od 13. do konce 15. století, Sborník Západočeského muzea v Plzni - Historie V, 59-84.

GABRIEL, F.-SMETANA, J., 1983: K vývoji výrobních okruhů červeně malované keramiky v severních Čechách - Zur Entwicklung der Productionsbereiche rot gemalter Keramik in Nordböhmen, AH 8, $119-138$.

GOŠ, V., 2007: Loštice. Město středověkých hrnčírů. Opava.

HAZLBAUER, Z.-ŠPAČEK, J., 1987: Př́ispěvek k výskytu bíle malované keramiky ve středním Polabí Beitrag zum Vorkommen der weiß-bemalten Keramik im Zentral-Elbengebiet, Studie a zprávy 1985, $30-55$.

HEJDOVÁ, D., 1981: The Glasshouse at Rejdice in North Eastern Bohemia, Late 16th - Early 17th Centuries, Journal of Glass Studies, 23, 18-33.

HEJNA, A.-RADOMĚRSKÝ, P., 1958: Penězokazecká dílna v jeskyni „Mincovna“ na Zlatém Koni u Koněprus - Die Münzfälscherwerkstatt in der Höhle „Mincovna“ am „Zlatý Kůñ“ bei Koněprusy, PA XLIX, 513-558. 
HORÁK, J., 2007: Archeologický výzkum dvorku č. p. 40 ve Filištínské ulici v Chrudimi. Diplomová práce na FF UK, Praha.

HORSCHIK, J., 1978: Steinzeug 15. bis 19. Jahrhundert. Von Bürgel bis Muskau. Dresden.

HOŠS̆O, J., 2004: Hranica medzi stredovekom a novovekom vo svetle archeologických nálezov keramiky Die Grenze zwischen dem Mittelalter und der Neuzeit im Gichte der archäologischen Keramikfunde, AH 29, 569-580.

CHVÁTAL, M.-ROUS, P.-VOKÁČ, M.-ZIMOLA, D., 2013: Střepy nádoby z raně novověkých dílen ledečských hrnčírů - Fragments of vessel from Early Modern-Age workshops of the potters in Ledeč, AVV 4, 184-200.

KLÁPŠTĚ, J., 2001: Mudrování u studny, AR LIII, 802.

KLÁPŠTĚ, J., ed., 2002: Archeologie středověkého domu v Mostě (čp. 226) - The archeology of medieval House (No. 226) in Most, Mediaevalia Archaelogica 4. Praha - Most.

KOHLPRATH, G., 1982: Hafner in Wien der Neuzeit. In: Keramische Bodenfunde aus Wien. Mitelalter Neuzeit, 129-139. Wien.

KOŠŤÁL, J., 2007: Archeologické nálezy z hradu Vízmburku. Diplomová práce na FF MU, Brno.

KOZÁKOVÁ, R., 2009: Restaurování archeologického skla z Chrudimi a možnosti konzervace metodou sol-gel. Bakalářská práce na Vysoké škole chemicko-technologické, Praha.

KOZÁKOVÁ, R.-FROLÍK, J., 2011: Bohatý soubor skla v Chrudimi, Hradební ulici - Ein reichhaltiges Glasensemble aus Chrudim (Hradební Straße), Historické sklo 5, 75-90.

KOZÁKOVÁ, R.-KLIKAROVÁ, L.-FROLÍK, J., 2010: Bohatý soubor skla z Chrudimi - Hradební ulice, Chrudimský vlastivědný sborník 14, 129-166.

KRAJÍC, R. a kol., 1998: Dům pasíře Prokopa v Táboře. Archeologický výzkum odpadní jímky v domě čp. 220. Písek.

KRUPPÉ, J., 1981: Gancarstwo późnośredniosieczne w Polsce. I-II. Wrocław.

KUDRNÁČ, J., 1973: Vojenský tábor z husitských válek v Klučově - Ein Militärlager aus der Zeit der Hussitenkriege in Klučov, PA LXIV, 105-142.

MĚŘÍNSKÝ, Z., 1969: Přehled typů loštické keramiky, jejich vývoj a datování, VVM XXI, 89-105.

MUSIL, J., 2008: Soubor raně novověkých hliněných dýmek z Hradební ulice v Chrudimi, Chrudimský vlastivědný sborník 12, 3-35.

- 2009: An assemblage of Late middle Age and Early Modern period ceramics from Rabštejnek Castle in the cadastral territory of Smrkový Týnec in the district of Chrudim, Studies in Post-Medieval Archaeology $3,45-64$.

- 2010: Soubor raně novověkých hliněných dýmek z Hradební ulice v Chrudimi - Eine Kollektion neuzeitlicher Tonpfeifen aus der Hradební-Gasse in Chrudim. In: Zaměřeno na středověk. Zdeňkovi Měřínskému k 60. narozeninám (Ungerman, Š.-Přichystalová, R.-Šulc, M.-Krejsová, J., edd.), 511-528, 792-794. Praha.

- 2010a: Pozdně středověký a raně novověký soubor keramiky z Chrudimi. Př́íspěvek k poznání nastupující novověké produkce - Late medieval and Early Modern ceramics from Chrudim, Východočeský sborník historický 17, 21-36.

- 2015: Hrnčířské podložky z Chrudimi. In: Středověká keramika v Čechách a na Moravě - otázky, metody, výsledky. Acta Fakulty Filozofické Západočeské univerzity v Plzni 7/2 (Čapek, L., ed.), 173-191. Plzeň.

NECHVÁTAL, B., 1967: Středověká keramika z Ledče nad Sázavou - Die mittelalterliche Keramik aus Ledeč nad Sázavou, AR XIX, 542-543.

NEKUDA, R., 1997: Mstěnice. Zaniklá středověká ves u Hrotovic 2. Dům a dvůr ve středověké vesnici. Brno.

- 1975: Pfaffenschleg. Zaniklá středověká ves u Slavonic - Pfaffenschlag. Mittelaalterliche Ortswüstung bei Slavonice. Brno.

- 1985: Mstěnice. Zaniklá středověká ves u Hrotovic 1. Hrádek - tvrz - dvůr - předsunutá opevnění. Brno.

NEKUDA, V.-REICHERTOVÁ, K., 1968: Středověká keramika v Čechách a na Moravě - Mittelalterliche Keramik in Böhmen und Mähren. Brno.

NETOLICKÝ, P., 2010: Dřevohliněné konstrukce z vrcholně středověké Chrudimi, Chrudimský vlastivědný sborník 14, 69-128.

NOVÁK, M., 2010: Pravěké osídlení Chrudimi - Hradební ulice, Chrudimský vlastivědný sborník 14, 29-67.

ORNA, J. et al., 2011: Keramická produkce města Plzně v období 14. a 15. století. Plzeň.

PAJER, J., 1982: Hromadný nález ze začátku 17. století ve Strážnici - Ein Massenfund aus dem Beginn des 17. Jahrhunderts in Strážnice. Strážnice.

- 1983: Počátky novověké keramiky ve Strážnici. Strážnice. 
- 2001: Novokřtěnecké fajánse ze Strachotína - Anababtist faiences from Strachotín. Mikulov.

PAVLIŠOVÁ, K., 2015: Středověká stavební keramika z Chrudimi z pohledu archeologie. Nepublikovaná bakalářská práce, Ústav historických věd, Filozofická fakulta, Univerzita Pardubice.

PAVLŮ, I., 1982: K počátkům Čáslavě. I. Katalog - Archeologické nálezy při městských hradbách, Praehistorica X - Varia Archaeologica 3, 75-160.

REICHERTOVÁ, K., 1968: Nález chlebové pece v Anežském klášteře v Praze 1, Na Františku - Der Fund eines Brotbackofens im St. Agnes-Kloster in Prag 1, Na Františku, AR XVIII, 220-229, 285-286, tab. II:5.

RIESEBIETER, O., 1921: Die deutsche Fayencen des 17. und 18. Jahrhundert. Leipzig.

RICHTER, M.-VOKOLEK, V., 1998: Hradec Králové. Slovanské hradiště a počátky středověkého města Hradec Králové. Ein slawischen Burgwall und Beginn einer Stadt. Praha - Hradec Králové.

SEDLÁČKOVÁ, H.-ROHANOVÁ, D. a kol., 2016: Renaissance and Baroque Glass from the Central Danube Region. Brno.

SEHNOUTKOVÁ, P., 2011: Chrudim, Filištínská ulice čp. 39/I, odpadní jímky XIXA, XIXB a XX (př́íspěvek k poznání hmotné kultury). Diplomová práce na FF MU, Brno.

SCHEUFLER, V., 1963: Problémy lidovosti v keramice - Das Problem der Volkstümlichkeit in der Keramik, Český lid L, 35-40.

- 1972: Lidové hrnčířství v českých zemích - Volkstümliche Töpferei in den böhmischen Ländern. Praha.

SCHEUFLER, V.-ŠTAJNOCHR, V.-TURNSKÝ, M., 1974: České mezzomajoliky - Die böhmische Mezzomajolika, ČNM A CXLIII, 171-184.

SOUKUP, M. B., 2003: Problémy zpracování archeologických nálezů z Vízmburka. In: Sláva a pád hradu Vízmburka (Koštál, J., ed.), 29-35. Hradec Králové.

ŠTAJNOCHR, V., 1990: České mezzomajoliky, MVP 28, 79-89.

- 1992: České majoliky, mezzomajoliky a polofajánse. Praha.

- 1998: Nové a starší nálezy střepů mezzomajolik, ASČ 2, 433-468.

ŠTAJNOCHR, V.-FRÖHLICH, J.-KRAJÍC, R.-MILITKÝ, J., 1998: Katalog střepových nálezů mezzomajolik, ASČ 2, 445-468.

TOMÁS̆EK, M., 1995: Archeologický výzkum hradebního pásma v Čáslavi v roce 1993 - Die archäologische Ausgrabung der Befestigungszone in Č́slav in Jahre 1993, AR XLVII, 444-454.

VAŘEKA, P., 1998: Proměny keramické produkce vrcholného a pozdního středověku v Čechách - The erratic character of ceramic production in High and Later Middle Age in Bohemia, AR L, 123-137.

- 2002: Keramika pozdního středověku až počátku novověku z areálu bývalých kasáren Jiřího $\mathrm{z}$ Poděbrad na náměstí Republiky v Praze 1 (zjištovací výzkum v letech 1998-1999), Archaeologica Pragensia 16, 217-250.

VENCL, S., 2001: Souvislosti chápání pojmu „nálezový celek“v české archeologii - The Term „Find Complex“" in Czech Archaeology: Its Use and Missuse, AR LIII, 592-614.

VOJTÍŠEK, J., 2016: Dva berní rejstř́iky města Chrudimi z let 1399-1402 - Two Tax Registers of the Town of Chrudim from the Years 1399-1402. In: Frolík, J.-Musil, J.-Richter, D.-Vojtíšek, J., Chrudim v době Karla IV., 93-181. Chrudim.

WOLF, O., 2002: K poznání hrnčířské produkce 13.-16. století v Chrudimi (archeologický výzkum ve Filištínské ulici čp. 37/I-40/I). Diplomová práce na FF MU, Brno.

ZÁPOTOCKÝ, M., 1978: Středověká keramika severočeského Polabí. Morfologie a relativní chronologie. Die mittelalterliche Keramik des nordböhmischen Elbegebiet. Morphologie und relative Chronologie, PA LIX, 171-238.

ZÁPOTOCKÝ, M., 1979: Katalog středověké keramiky severočeského Polabí. Výzkumy v Čechách Supplementum. Praha.

ŽEGKLITZ, J., 2011: Výsledky archeologického výzkumu renesanční sklárny v Broumech, Historické sklo 5 - Sborník pro dějiny skla, 167-212.

\section{Zusammenfassung}

\section{Abwassergrube 938 in Chrudim - Hradební-Straße. Versuch einer Statusbestimmung ihres Besitzers}

Im Jahr 2006 wurde im historischen Stadtkern der ostböhmischen Stadt Chrudim eine archäologische Rettungsgrabung durchgeführt, und zwar auf den sich in der Hradební-Straße befindenden Parzellen der verschwundenen Häuser Nr. 14/I und 15/I sowie im ursprünglich zu 
Nr. 10/I gehörenden Garten. Ein bedeutender Bestandteil des Befundbildes sind Abwasser- und Abfallgruben (Abb. 1 und 2), die chronologisch den Zeitraum zwischen der Wende des 13. und 14. Jahrhunderts und dem achtzehnten Jahrhundert abdecken. Alle Abwasser- und Abfallgruben wurden entsprechend ihren natürlichen Schichten untersucht, was es erlaubte, die Art ihrer Befüllung detailliert zu beobachten. In den Abwassergruben befand sich ursprünglich eine leicht unbefestigte Verfüllung, die sich nach und nach absetzte, sodass sie eine charakteristische Schichtenfolge mit Ablagerungen bildete, deren Ränder an den Grubenwänden entlang nach oben verlaufen (U-förmiges Profil). Der Vorgang des sich allmählichen Absetzens konnte in einem Intervall von bis zu zwei Metern erfolgen. Das sich Absetzen des Inhalts machte sich erst sehr lange nachdem eine Grube ihre Funktion verlor bemerkbar. Unsere Aufmerksamkeit konzentriert sich auf Abwassergrube Nr. 938, die in der Mitte der größten Abwassergrubenkonzentration in der nordwestlichen Ecke des zu Haus Nr. 14/I gehörenden kleinen Hofes liegt (Abb. 2). Grube 938 hat einen annähernd runden Durchmesser von 1,7 m. Der zylinderförmige Grubenkörper ist mit Plänersteinen ausgemauert. Die Grube war 6,5 m tief. Bis in die Tiefe von ungefähr 4,5 $\mathrm{m}$ hat die Grube den gleichen Umfang, dann verjüngt sie sich langsam bis zu einem Durchmesser von $0,8 \mathrm{~m}$. Der Boden ist eben und besteht aus einem felsigen Untergrund. Die Verfüllung der Grube erfolgte im Einklang mit den oben aufgeführten Erkenntnissen. Von diesem Schema weichen mehrere mehr oder weniger waagerechte Schichten ab, welche die Grenze zwischen den jeweiligen Schichten/Ablagerungen mit abgesetzter Mitte darstellen. Wir nehmen an, dass diese waagerechten Grenzen beim Ausklauben der Grube entstanden sind (Abb. 3).

Eine Konfrontation mit den erhaltenen schriftlichen Quellen bringt gewisse Probleme mit sich. Der ganze Häuserblock befand sich in einem Viertel, das Klášterská (Klosterviertel), später dann Bohatá (Reiches Viertel) genannt wurde. Die mit ihm verbundenen schriftlichen Quellen (Stadtbücher) sind erst ab dem 17. Jahrhundert erhalten geblieben. Sie belegen, dass die meisten Häuser im Dreißigjährigen Krieg verschwanden und neu gebaut werden mussten. Die älteste Erwähnung, dass die Parzelle wüst war, stammt aus dem Jahr 1641. Ein Eigentumsverzeichnis aus dem Jahr 1735 belegt, dass in dem Haus ein Gasthaus betrieben wurde. Die schriftlichen und archäologischen Zeugnisse gehen aneinander vorbei.

Bei der Analyse der aus Abwassergrube 938 stammenden Keramik wurden insgesamt vier ausgeprägte, zeitlich und technologisch unterschiedliche Horizonte abgegrenzt. Der obere Horizont (1. Phase) wurde ins 17.-18. Jahrhundert datiert (Abb. 4 bis 6). Die Grundformen der Keramik stellen verschiedene Henkeltopfvarianten, Krüge und tellerartige Schüsseln dar. Eine deutliche Komponente bilden tellerartige Majolika- und Mezzomajolika-Schüsseln, vor 1628 hergestellte südmährische Habaner Fayencen, Muskauer Steinzeug und heimische Imitationen davon dar. Zu den Sonderformen zählen der Torso einer Keramikplastik (?), der Teil einer kleinen Keramikglocke, eine kleine Form zur Herstellung von anthropomorphen Applikationen bei der Herstellung von Ofenkacheln und das Bruchstück eines grünglasierten Pfeifenholms. Provenienzmäßig handelt es sich dabei um ein deutsches (schlesisches?) Erzeugnis.

Eine Veränderung in der Zusammensetzung der Keramikfunde wurde auf dem Niveau von Verfüllung D2/128 registriert, wo ein ins 16.-17. Jahrhundert datierter Horizont (2. Phase) spezifiziert wurde (Abb. 7). Die meiste Keramik gehörte zur mit Oxidationsbrand gebrannten und teilweise transparent glasierten Keramikware mit weiß-grauem und orangefarbenem Scherben, deren Gefäßinnenseiten eine braunrote oder gelborangenfarbene transparente Glasur aufweisen. Die Grundformen der Keramik stellen verschiedene Größenvarianten von Töpfen dar. In der Schicht befanden sich unter anderem auch Topfkacheln mit rechteckiger Mündung und Fragmente einer Kachel mit der in spätgotischer Majuskelschrift angebrachten Inschrift „PANE...“.

Der Zeit der größten Blüte der Stadt (zweite Hälfte 15. bis Mitte 16. Jahrhundert) wurde der Horizont der 3. Phase zugeordnet (Abb. 8-10, Abb. 11:1-4, 12). Hier dominiert glasurlose und zumeist rädchenverzierte Reduktionskeramik aus den Produktionsgebieten Südböhmens und Südmährens (Ledeč nad Sázavou?). Eine bedeutende Komponente bildet glasurlose, mit Oxidationsbrand sehr hart gebrannte lokale Keramikware mit charakteristischen sog. Chrudimer Bechern. Eine weitere Gruppe stellt lokale, teilweise glasierte (braunrot transparent) 
Oxidationskeramik vom Typ Husova-Straße dar. Zu den Importen zählt rote mit Oxidationsbrand gebrannte Keramik mit Rädchenverzierung oder weißer Bemalung (aus Mittelböhmen?). Die Grundformen der Keramik stellen verschiedene Größenvarianten von Töpfen mit und ohne Henkel und der größten Ausbauchung im oberen Drittel der Gefäße, Krüge, Becher, Schalen mit Ausguss und neuzeitliche Prototypen sog. Wöchnerinnenterrinen mit einem oder zwei Bügelhenkeln, Dreifüße mit offener Tülle und Deckel dar. Die Funde werden noch ergänzt um Topfkacheln mit Rechteckmündung (bei einigen Exemplaren wurde die Randleiste der Innenseite mit einem Rädchen nachgezogen).

Für die letzten zwei Meter der Verfüllung wurde ein Horizont spezifiziert (4. Phase), der anhand der Keramikfunde in die Zeit der zweiten Hälfte des 14. bis in die erste Hälfte des 15. Jahrhunderts datiert wurde (Abb. 11:5-6, Abb. 13-15). Im Keramikmaterial ist ein Zustrom an luxuriöserer Importkeramik (Loschtitzer und glasierte Keramik) sowie eine höhere Anzahl an Bechern und Krügen erkennbar. Auch kann man ein Zustrom von metallglänzender Reduktionskeramik in die ursprüngliche Zone der mit Oxidationsbrand gebrannten Keramik beobachten. Für die ältere Periode sind fassförmige Henkeltöpfe mit ovalem Rand und Spiralbandverzierung am Topfkörper sowie Henkeltöpfe mit unechtem, stark nach außen umgeschlagenem Kragenrand die typischen Formen. Von der zuletzt erwähnten Topfvariante führt eine direkte Entwicklungslinie zum sog. Chrudimer Becher. Technologisch ist die an der Grubenbasis entdeckte Keramikware noch mit Bodenmarken versehen, die auch in den oberen Partien des Horizontes (4. Phase) auftreten können.

Interessante Ergebnisse brachte die Analyse von Glas. Eine zahlenmäßig umfangreiche Gruppe kann in drei chronologische Grundetappen unterteilt werden, die von der Datierung der Keramikfunde leicht abweicht. Der untere Teil der Verfüllung (Abb. 3 - 4. Phase) enthielt gotisches Glas. Es ist sehr torsohaft erhalten geblieben. Identifiziert wurden mindestens sieben Gefäße, und zwar ein Becher böhmischen Typs und eine Flasche aus der Zeit zwischen der zweiten Hälfte des 14. Jahrhunderts bis zum 15. Jahrhundert. In Ablagerung D2/141 wurden Fragmente einer bauchigen Flasche gefunden. Oberhalb der Übergangsablagerung D2/129 mit dem Fund eines spätgotischen Bechrs mit optischem Dekor (3. Phase, Abb. 18:7) befinden sich Ablagerungen mit Glas, das eine renaissancezeitliche Formgebung aus der zweiten Hälfte des 16. und dem ersten Drittel des 17. Jahrhunderts (2. Phase) aufweist. Identifiziert wurden Flaschen, kleine Becher, Kannen, Trinkbecher, wahrscheinlich auch kleine Krüge, Kugeln, ein Ring und Fensterglas (Abb. 16, 17:1-9). Beachtung verdient eine Luxusflasche, deren Verzierung aus einer heimischen Analogie der venezianischen Filigrantechnik mit eingeschmolzenen roten und weißen Stäbchen besteht (Abb. 18:1). Die am meisten vertretene Form ist die eines Trinkbechers mit spindelförmiger Kuppa und einem aus gewickelten Glasfasern bestehenden Fuß mit optischem Dekor. Rekonstruiert wurden neun ganze Profile und Bruchstücke von mindestens zwanzig weiteren Exemplaren, von denen einige völlig identisch sind und wahrscheinlich eine Garnitur bildeten (Abb. 17:6). Fundmäßig unterschiedlich ist der obere Teil der Verfüllung mit in das 18. Jahrhundert datiertem barocken Kreideglas oder jüngerem Glas (1. Phase). Das Glas war glatt oder hatte eine Randschliffverzierung. Es handelte sich um starkwandiges Glas, das von breiteren Gefäßböden, wahrscheinlich von Trinkkrügen stammte. Identifiziert wurden auch mächtige hüttenverzierte Henkel, ein enger Flaschenhals und ein Röhrchenteil. Drei Fragmente waren auch mit einer Rädchengravur verziert (Abb. 17:10-11).

Nichtkeramikfunde sind größtenteils als Bruchstücke von Eisengegenständen (insgesamt 543 Stück), Bronzefragmente, Gegenstände und als Fragmente aus Bein und Stein vertreten. Ebenfalls vertreten sind Schlacke und Textilfragmente, Fragmente von Baustoffen (Ziegelsteine, Hohlziegel) und Lehmbewurf.

Die Eisengegenstände liefern keine allzu eindeutige Aussage, die meisten von ihnen sind unbestimmbar. Unter den bestimmbaren dominieren Nägel und Fragmente von Baubeschlägen (Abb. 19:1, 2, 5, 7). Entdeckt wurden auch mehrere Bronzegegenstände (ein Kleiderhaken [?], ein Knopf, eine Schnalle [?] und das Fragment einer Nadel - Abb. 19:3, 4, 6, 8). Alle stammmen aus dem nach dem Dreißigjährigen Krieg entstandenen Teil der Verfüllung. Unter den 
Buntmetallgegenständen fand man auch eine kleine aus Messingblech gehämmerte Hand, die wahrscheinlich zu Votivzwecken diente (Abb. 18:2). Die Aufzählung von Metallgegenständen beschließen wir mit vier Münzen, von denen drei aus dem Renaissancehorizont und eine aus dem gotischen Horizont stammen. Keine von ihnen ist bestimmbar.

Zur Tischausstattung zählen Messergriffe aus Bein (Abb. 18:3) und eine kleine Dose aus Bein mit Schraubverschluss, die als Rauchutensilie identifiziert wurde (Abb. 18:5). Zu den Artefakten aus Bein zählen wir auch ein unbearbeitetes Geweih, das wir als Trophäe ansehen (Abb. 18:6). Die Aufzählung beschließen wir mit Steinartefakten (Schleifstein - Abb. 19:9) und Feuersteinen, ggf. deren Bruchstücke (Abb. 20).

Der Analyse des archäologischen Materials nach zu urteilen war die Grube lange in Betrieb. Angelegt wurde sie den aus dem ältesten Horizont stammenden Funden nach in der zweiten Hälfte des 14. Jahrhunderts. Die chronologischen (drei bis fünf Zeiträume) und stratigraphischen Grenzen belegen, dass die Grube wiederholt geleert wurde, und zwar mindestens zweibis dreimal. Niemals jedoch völlig. Die Grube hat wohl am ehesten im Zusammenhang mit den Ereignissen des Dreißigjährigen Krieges aufgehört zu funktionieren (Abb. 3).

Die Funde lassen eine luxuriösere Haushaltsausstattung erkennen (Glasfunde, ferner Rauchutensilien, Jagdtrophäe), sie erlauben jedoch nicht, Überlegungen über das vom Besitzer der Immobilie ausgeübte Handwerk oder Gewerbe anzustellen. Die Schicht mit der größten Menge an luxuriöseren Funden (D2/118 - Münzen, Besteckteile, Geweih) lieferte auch einen großen Komplex an Glas, der sich aus einer Serie gleicher Gefäße zusammensetzte. Das deutet auf eine wahrscheinlich nach einer Katastrophe erfolgte Räumung hin (offenbar im Zusammenhang mit den Ereignissen des Dreißigjährigen Krieges).

Hinsichtlich des Aussagewertes der verschiedenen archäologischen Objekte ist Grube 938 ein Beleg dessen, dass bei sorgfältig durchgeführten Geländearbeiten und Dokumentationen sowie einer sorgfältigen Bearbeitung solche Objekte wichtige Erkenntnisse liefern können, die für gewöhnlich als weniger wertvoll angesehen werden. Eine ähnliche Entwicklung können wir nämlich auch bei weiteren Abwassergruben identifizieren (Grube 973 - Abb. 21 oder Grube 932 - Abb. 22).

PhDr. Jan Frolík, CSc., Archeologický ústav AV ČR, Praha, v. v. i., Letenská 4, 11801 Praha 1, Česká republika,frolik@arup.cas.cz

Mgr. Romana Kozáková, Národní muzeum, Historické muzeum, Oddělení správy, evidence a péče o sbírky, Ústřední depozitář I., Tyršova 207, 41155 Terezín u Litoměřic, Česká republika, romana_kozakova@nm.cz

PhDr. Jan Musil, Regionální muzeum v Chrudimi, Široká 86, 53701 Chrudim, Česká republika, musil@muzeumcr.cz 
